\title{
Prostaglandin $I_{2}$ is responsible for ameliorating prostaglandin $E_{2}$ stress in stimulating the expression of tumor necrosis factor a in a $\beta$-amyloid protein -dependent mechanism
}

\author{
Shao-Qin Zheng ${ }^{1}$, Zi-Yi Gong ${ }^{1}$, Chen-Di Lu ${ }^{1}$ and Pu Wang ${ }^{1}$ \\ ${ }^{1}$ The College of Life and Health Sciences, Northeastern University, Shenyang, P. R. China \\ Correspondence to: Pu Wang, email: wangpu@mail.neu.edu.cn \\ Keywords: prostaglandin $\mathrm{I}_{2}$, prostaglandin $\mathrm{E}_{2}$, tumour necrosis factor a, $\beta$-amyloid protein, p38, Gerotarget \\ $\begin{array}{lll}\text { Received: March 04, } 2017 \quad \text { Accepted: May 08, } 2017 & \text { Published: June 13, } 2017\end{array}$ \\ Copyright: Zheng et al. This is an open-access article distributed under the terms of the Creative Commons Attribution License 3.0 (CC BY \\ 3.0), which permits unrestricted use, distribution, and reproduction in any medium, provided the original author and source are credited.
}

\section{ABSTRACT}

Cyclooxygenase-2 (COX-2) has been found to be induced during the early stage of Alzheimer's disease (AD). Using mouse-derived astrocyte and APP/PS1 transgenic (Tg) mice as model systems, we firstly elucidated the mechanisms underlying COX2 metabolic production including prostaglandin (PG) $E_{2}-$ and $P \mathrm{II}_{2}$-mediated tumor necrosis factor a (TNF-a) regulation. Specifically, $\mathrm{PGE}_{2}$ accumulation in astrocyte activated the p38 and JNK/c-Jun signaling pathways via phosphorylation, resulting in TNF-a expression. In contrast, the administration of PGI $_{2}$ attenuated the effects of $\mathrm{PGE}_{2}$ in stimulating the production of TNF-a by inhibiting the activity of TNF-a promoter and the binding activity of AP1 on the promoter of TNF-a. Moreover, our data also showed that not only $A \beta_{1-42}$ oligomers but also $A \beta_{1-42}$ fibrils have the ability to involve in mediating the antagonistic effects of $\mathrm{PGE}_{2}$ and $\mathrm{PGI}_{2}$ on regulating the expression of TNF-a via a p38- and JNK/c-Jun-dependent, AP1-transactivating mechanism. Reciprocally, the production of TNF-a finally accelerated the deposition of $\beta$-amyloid protein $(A \beta)_{1-42}$ in $\beta$-amyloid plaques (APs), which contribute to the cognitive decline of AD.

\section{INTRODUCTION}

Cycooxygenase-2 (COX-2) and prostaglandins (PGs) were found to be upregulated at the early stage of Alzheimer's disease (AD) two decades ago [1]. Unfortunately, the initial mechanistic investigations of COX-2 and PGs in AD were disrupted by the failure of clinical trials of COX-2-specific inhibitors [2]. However, the results of these clinical trials have been called into question due to the lack of the guidance of a mechanistic study. Generally, COX-2 exhibits multiple biological functions and is thought to regulate the pathogenesis of $\mathrm{AD}$ via its metabolic products, including $\mathrm{PGE}_{2}, \mathrm{PGD}_{2}$ [and its dehydration end product 15 -deoxy- $\Delta^{12,14}-\mathrm{PGJ}_{2}$ $\left.\left(15 \mathrm{~d}-\mathrm{PGJ}_{2}\right)\right], \mathrm{PGI}_{2}, \mathrm{PGF}_{2} \alpha$ and TXA 2 [3]. Among these PGs, the roles of $\mathrm{PGE}_{2}$ and $\mathrm{PGI}_{2}$ in neuroinflammation have been a focus of study [4], because these PGs potentially contribute to the production of $\beta$-amyloid protein $(A \beta)$ and the hyperphosphorylation of tau in the brain $[5,6]$. As indicated, COX-2 has been suggested to have a potential role of in neuroinflammation [7]. In addition, neuroinflammation is involved in $A \beta$ deposition and tau phosphorylation [8], which contribute to the progression of AD.

The investigation of $\mathrm{PGE}_{2}$ in $\mathrm{AD}$ was initially prompted by the elevated levels of $\mathrm{PGE}_{2}$ in the cerebrospinal fluid (CSF) of AD patients [9]. The involvement of $\mathrm{PGE}_{2}$ in $\mathrm{AD}$ was shown to involve stimulation of $A \beta$ production through the EP4 receptor [10]. Although this observation was called into question by clinical studies that showed that long-term treatment of $\mathrm{AD}$ patients with celecoxib or rofecoxib did not reduce $\mathrm{A} \beta$ content in the pathology of the disease [11, 12], we could not rule out their roles in suppressing the production of $\mathrm{PGD}_{2}$ or $15 \mathrm{~d}-\mathrm{PGJ}_{2}$, which exhibit anti-inflammatory functions and alleviate the effects of $\mathrm{PGE}_{2}$ stress on inflammation $[13,14]$. Aside from the roles of $\mathrm{PGE}_{2}$ in neuroinflammation, $\mathrm{PGI}_{2}$ signalling was shown to facilitate joint inflammation in a mouse model of collagen-induced arthritis, while the administration of a $\mathrm{PGI}_{2}$ antagonist 
reduced pain and inflammation in rodent models of hyperalgesia and chronic arthritis [15]. In contrast to the seemingly pro-inflammatory properties of $\mathrm{PGI}_{2}$, its effects in certain conditions are still debated [5]. For example, PGI $_{2}$ has been studied as a potentially important suppressor of allergen-induced inflammation [5]. Thus, the effects of $\mathrm{PGI}_{2}$ on the inflammatory reactions remain uncertain in peripheral or central tissues.

Although we could not find direct evidence of the relationship between $\mathrm{PGI}_{2}$ and neuroinflammation, a growing body of research has revealed that $\mathrm{PGI}_{2}$ has the ability to regulate the synthesis of cytokines [16]. For example, treatment with $\mathrm{PGI}_{2}$ analogs, including iloprost and Treprostinil suppressed tumour necrosis factor $\alpha$ (TNF- $\alpha$ ) expression in human myeloid dendritic cells [16]. In contrast, $\mathrm{PGE}_{2}$ treatment elevated the expression of TNF- $\alpha$ in SH-SY5Y cells [14]. However, the antagonistic regulatory mechanisms of $\mathrm{TNF}-\alpha$ that are mediated by $\mathrm{PGE}_{2}$ and $\mathrm{PGI}_{2}$ during the course of $\mathrm{AD}$ development are not often studied. Although little is known about the relationship between PGs and TNF- $\alpha$, TNF- $\alpha$ has been suggested to regulate the cleavage of amyloid precursor protein (APP) [17-20]. For example, TNF- $\alpha$ treatment upregulates the expression of BACE-1 in APPsw $\mathrm{Tg}$ mice [20]. Additionally, TNF- $\alpha$ stimulates $\gamma$-cleavage of APP in HEK293 cells [18]. For the reason, TNF- $\alpha$ is thought to have the ability to induce the expression or phosphorylation of $\gamma$-secretases, including presenilin (PS) 1, PS2 and nicastrin (NCT) in HEK293 or human neuronal cells $[17,19]$. When considered together, these data prompted us to investigate the roles of $\mathrm{PGE}_{2}$ and $\mathrm{PGI}_{2}$ in regulating the expression of TNF- $\alpha$ during the course of AD development.

Accordingly, we demonstrated that $\mathrm{PGE}_{2}$ induction during the early stage of AD stimulated the expression of TNF- $\alpha$ via an $\mathrm{A} \beta_{1-42}$-dependent, AP1-activating pathway. In contrast, $\mathrm{PGI}_{2}$ attenuated the effects of $\mathrm{PGE}_{2}$ in stimulating the expression of TNF- $\alpha$ by depressing the activity of the p38 and JNK/c-Jun pathways. In addition, not only $\mathrm{A} \beta$ oligomers but also $\mathrm{A} \beta$ fibrils had the ability to stimulate the expression of TNF- $\alpha$. Reciprocally, TNF- $\alpha$ accumulation in or secretion from astrocytes accelerated $\mathrm{A} \beta$ deposition in APs.

\section{RESULTS}

\section{TNF- $\alpha$ is markedly upregulated in the brains of AD patients and APP/PS1 transgenic mice}

Because previous studies have suggested that TNF- $\alpha$ aggravates the pathogenesis of $\mathrm{AD}$ [21], we evaluated the expression levels of TNF- $\alpha$ in AD patients and APP/ PS1 transgenic mice at 6 or 9 months of age. As shown in Figure 1A, TNF- $\alpha$ immunostaining progressively increased throughout the course of $\mathrm{AD}$ development. Interestingly, morphological analysis demonstrated that positive staining for TNF- $\alpha$ was located in the neurons (Figures. 1B, 1C). In line with these observations in AD patients, in 6-month-old APP/PS1 mice, TNF- $\alpha$ immunostaining was strongly increased in the cerebral cortex and dentate gyrus (DG) region of the hippocampus compared to that in WT C57BL/6 mice (Figure 1D). To further confirm this finding, we examined the mRNA and protein levels of TNF- $\alpha$ in these APP/PS1 Tg mice by qRTPCR and ELISA. In agreement with the immunostaining data, our results demonstrated the upregulation of TNF- $\alpha$ mRNA and protein levels in the cerebral cortex and DG region of the hippocampus (Figure 1E). In addition, we found that TNF- $\alpha$ was also increased in the APP/ PS1 mice at 9 months of age (Figure 1F). Similarly, the mRNA and protein levels of TNF- $\alpha$ were sustained above basal levels (Figure 1G). These data reveal that TNF- $\alpha$ is upregulated with the development/progression of AD. As $\mathrm{A} \beta$ is progressively deposited in $\beta$-amyloid plaques (APs) during the course of AD development (Figure $1 \mathrm{H}$ ), our data indicate a possible role of $\mathrm{A} \beta$ aggregation in TNF- $\alpha$ stimulation.

\section{TNF- $\alpha$ was either synthesized in neurons or translocated from astrocytes during the course of AD development}

We next aimed to elucidate the origination of TNF- $\alpha$ during the progression of $\mathrm{AD}$. As a result, the primary cultured neuronal cells showed positive TNF- $\alpha$ staining (Figure 2A). However, these observations could not exclude that high levels of TNF- $\alpha$ might be produced by astrocytes, which in turn translocate to neuronal cells. To verify this hypothesis, we next showed that the activity of astrocyte was stimulated in 6- and 9-month-old APP/ PS1 Tg mice (Figures 2B, 2C). More specifically, we cocultured primary cultured astrocytes or D1A cells in the upper chamber of transwells while culturing $\mathrm{n} 2 \mathrm{a}$ cells in the lower chamber. After $24 \mathrm{~h}$, TNF- $\alpha$ immunofluorescence was enhanced in the n2a cells (Figure 2D). To further confirm this observation, experiments were carried out to determine if TNF- $\alpha$ secreted from primary cultured astrocytes or D1A cells had the ability to bind to neurons of cultured slices of C57BL/6 mouse brains. As expected, our data revealed that TNF- $\alpha$ staining was elevated in neurons of the C57BL/6 brains that were co-cultured with astrocytes (Figure 2E). In addition, the highly induced TNF- $\alpha$ could stimulate the activity of microglia (Figure $2 \mathrm{~F}$ ), which further induced the expression of TNF- $\alpha$ in microglia (Figure $2 \mathrm{G}$ ). Moreover, TNF- $\alpha$ injection (i.c.v.) was also found to induce the production of additional TNF- $\alpha$ in the cerebral cortex of WT mice (Figure 2H). To exclude the possibility that the increasement of TNF- $\alpha$ was caused by the binding of exogenous TNF- $\alpha$ on neurons, 
the mRNA and protein levels of TNF- $\alpha$ were further verified by qRT-PCR and ELISA (Figure 2I). In D1A cells, the luciferase activity and binding activity of AP-1 on the TNF- $\alpha$ promoter were determined, and the results demonstrated that the promoter and binding activity were elevated after TNF- $\alpha$ treatment (Figure 2J). Therefore, it is clear that TNF- $\alpha$ was either synthesized in neurons or translocated from astrocytes during the course of AD development (Figure 2K).

COX-2 induces the expression of TNF- $\alpha$ by altering the balance between $\mathrm{PGE}_{2}$ and $\mathrm{PGI}_{2}$ in APP/PS1 Tg mice

Because COX-2 expression is elevated during the early stage of $\mathrm{AD}$ and is associated with $\mathrm{A} \beta$ deposition
[22], we studied whether COX-2 inhibition by NS398 could downregulate the expression of TNF- $\alpha$. We intranasally administered NS398 $(50 \mu \mathrm{g} / \mathrm{kg} / \mathrm{d})$ to APP/ PS1 mice for 6 months before they were sacrificed. The results demonstrated that NS398 administration decreased the mRNA and protein expression of TNF- $\alpha$ (Figures 3A, $3 B)$. To further validate the above results, we injected (i.c.v.) APP/PS1 mice at 6 months of age with NS398 (2 $\mu \mathrm{g} / 5 \mu \mathrm{l})$. After $24 \mathrm{~h}$, the brains of the mice were collected, and the expression of TNF- $\alpha$ was determined. The mRNA and protein expression of TNF- $\alpha$ was highly induced in the APP/PS1 mice, and this effect was blocked by NS398 injection (Figures 3C, 3D). These observations clearly indicate that COX-2 elevation in APP/PS1 Tg mice stimulated the expression of TNF- $\alpha$.

To furhter validate the critical roles of $\mathrm{COX}-2$ in mediating the effects of APP/PS1 overexpression on

A

Mild

Mild Moderate
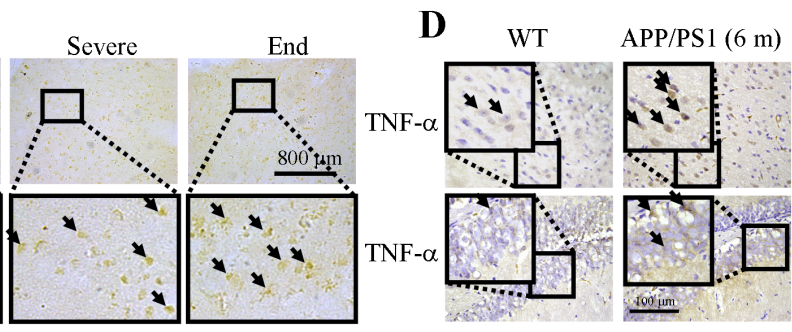

$\mathbf{E}$
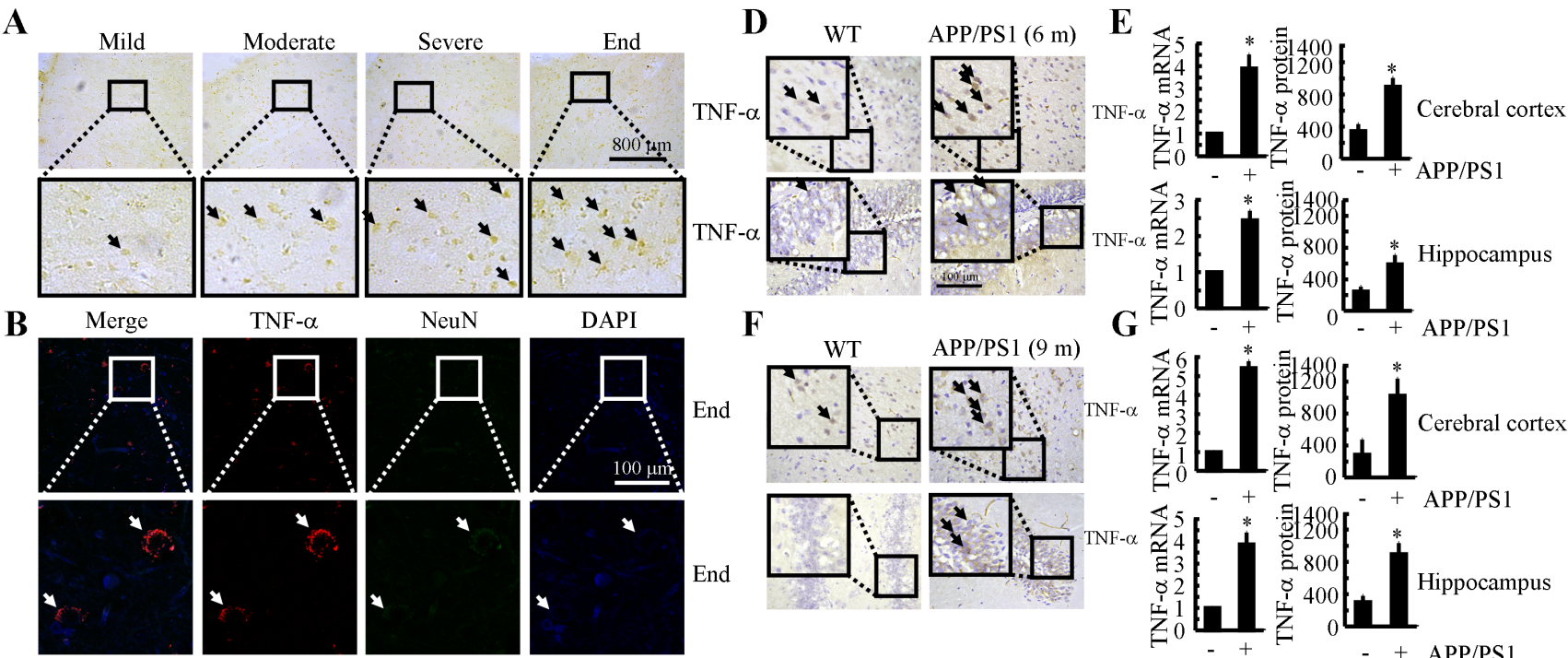

F
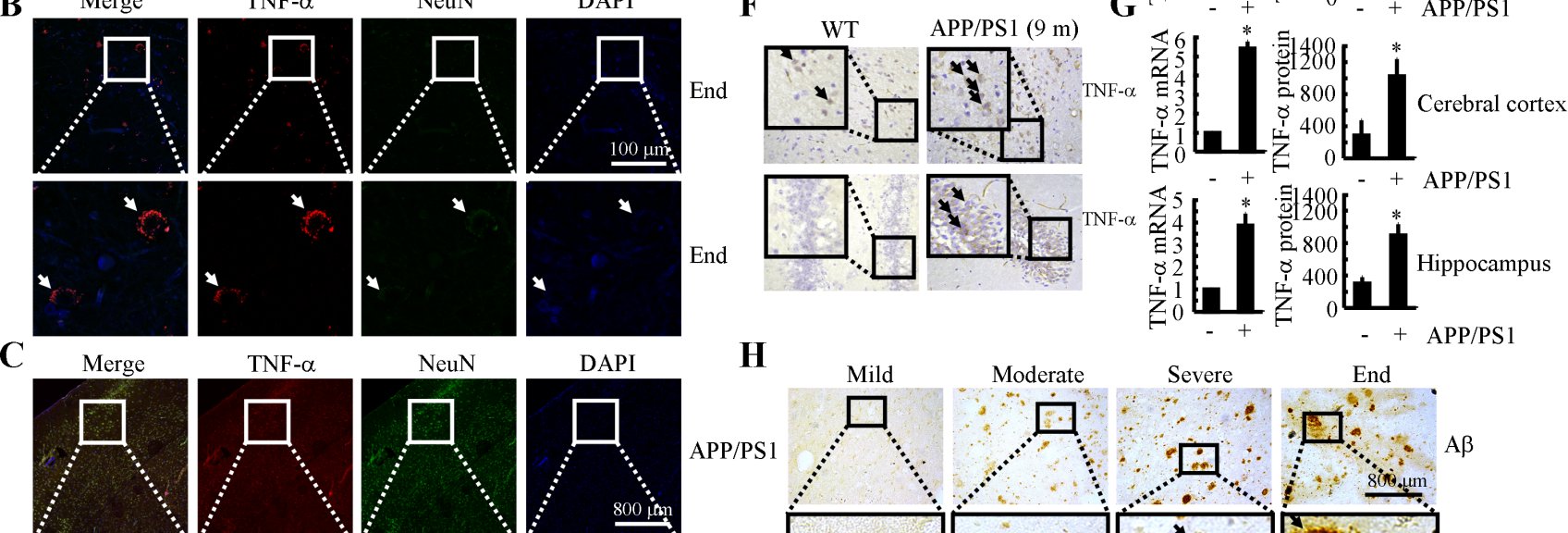

TNF- $\alpha$
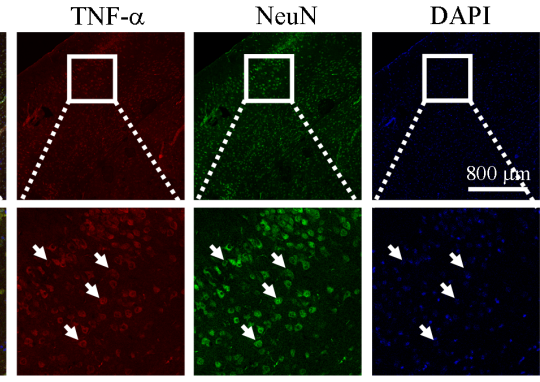

$\mathbf{H}$

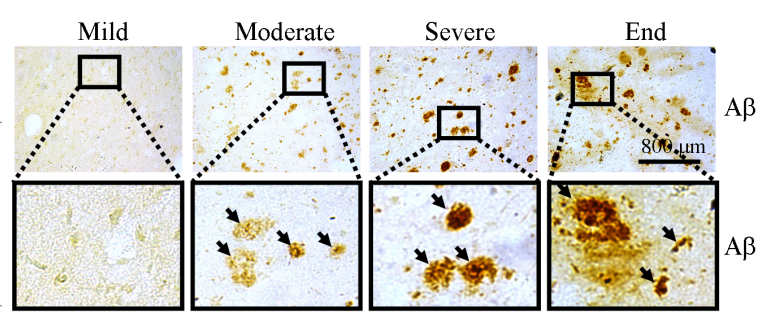

Figure 1: TNF- $\alpha$ expression was progressively elevated with A $\beta$ deposition in APs during the course of AD development. A., B., H. The tissue blocks of human brains at different stages of AD were collected by the New York Brain Bank at Columbia University. Free-floating slices $(40 \mu \mathrm{m})$ were prepared by cryostat $(n=1)$. A., H. The immunoreactivity of TNF- $\alpha$ and A $\beta$ was determined by immunohistochemistry using an anti-TNF- $\alpha$ or $-\mathrm{A} \beta$ antibody. The arrows demonstrated the positive staining of TNF- $\alpha$ or A $\beta$. B. The slices of human or mouse brains were double-stained with TNF- $\alpha$ (red) or NeuN (green) antibodies before being observed under confocal microscopy. C.- G. The brains of WT or APP/PS1 transgenic mice at 6 or 9 months of age were collected following anesthesia and perfusion $(n=9)$. C. The slices of human or mouse brains were double-stained with TNF- $\alpha$ (red) or NeuN (green) antibodies before being observed under confocal microscopy. D., F. The immunoreactivity of TNF- $\alpha$ was determined by immunohistochemistry using an antiTNF- $\alpha$ antibody. The arrows demonstrated the positive staining of TNF- $\alpha$. E., G. TNF- $\alpha$ protein and mRNA levels were determined by TNF- $\alpha$ enzyme immunoassay kits and qRT-PCR, respectively. Total amounts of protein and GAPDH served as an internal control. *, $p<$ 0.05 with respect to WT control. 
upregulating the expression of TNF- $\alpha$, experiments were carried out in COX-2 Tg mice. The results demonstrated that COX-2 overexpression induced the expression of TNF- $\alpha$ in C57BL/6 mice (Figures 3E, 3F). The strong induction of TNF- $\alpha$ expression was markedly attenuated by NS398 treatment in COX-2 Tg mice (Figures 3E, 3F). This observation not only confirmed the critical role of COX-2 in the upregulation of the expression of TNF- $\alpha$ in the APP/PS1 and COX-2 Tg mice but also indicated the possible effects of COX-2 metabolic products, including $\mathrm{PGE}_{2}$ and $\mathrm{PGI}_{2}$, in regulating the expression of TNF- $\alpha$. In addition, it was evident that $\mathrm{PGE}_{2}(2 \mu \mathrm{g} / 5 \mu \mathrm{l})$ injection (i.c.v.) stimulated the expression of TNF- $\alpha$ in the cerebral cortex of the mice (Figures 3G, Supplementary Figure
1A). The mRNA and protein levels of TNF- $\alpha$ were detected using qRT-PCR and ELISA. The results showed that $\mathrm{PGE}_{2}$ injection (i.c.v.) increased the expression of TNF- $\alpha$ in the cerebral cortex of the WT mice (Figure 3H). To further verify the key role of $\mathrm{PGE}_{2}$ in upregulating the expression of TNF- $\alpha$ in vivo, we combined i.c.v. injection with live animal imaging. As described in Figure $3 \mathrm{~K}$, D1A cells that were transfected with TNF- $\alpha$ promoter constructs were pre-seeded in the right lateral ventricle of WT mice at 6 months of age, whereas $\operatorname{PGE}_{2}(2 \mu \mathrm{g} / 5 \mu \mathrm{l})$ was injected into the left ventricle of the same mice. After $24 \mathrm{~h}$, luciferin was injected (i.c.v.) into the same ventricle, and live animal imaging was then conducted. The results showed that $\mathrm{PGE}_{2}$ increased the luciferase activity of

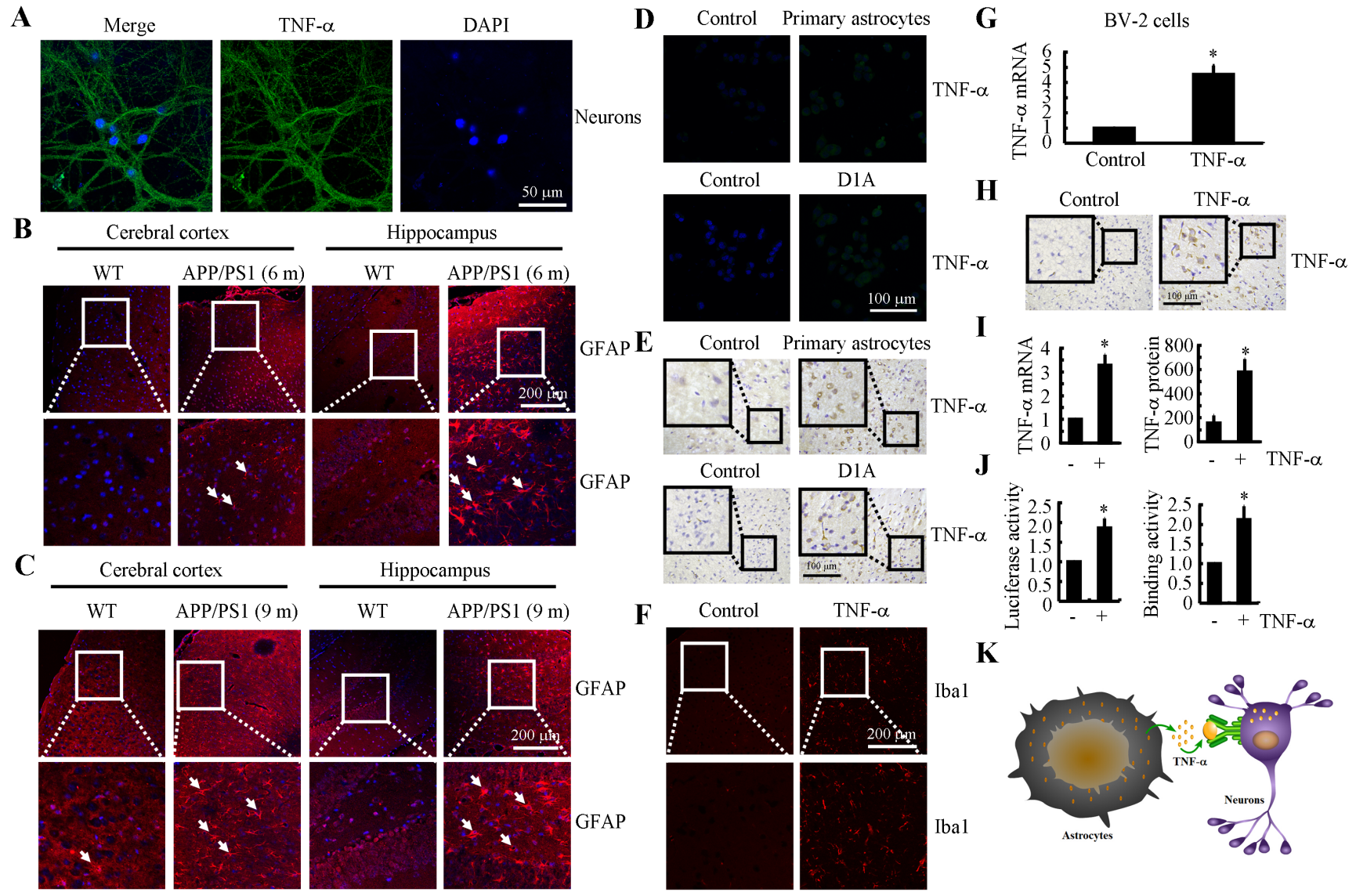

Figure 2: TNF- $\alpha$ was either synthesized in neurons or translocated from astrocytes during the course of AD development. A. The neurons were separated and cultured from the hippocampus of new-born C57BL/6 mice. The cells were stained with TNF- $\alpha$ antibody and DAPI. B., C.The brains of WT or APP/PS1 transgenic mice at 6 or 9 months of age were collected following anaesthetization and perfusion of the mice $(n=10)$. The activity of astrocytes was determined by staining with GFAP. D., E. n2a cells or freshly collected slices were co-cultured with primary astrocytes or D1A cells. The immunoreactivity for TNF- $\alpha$ was determined via immunofluorescence or immunohistochemistry. F. TNF- $\alpha(10 \mathrm{ng} / 5 \mu \mathrm{l})$ was injected (i.c.v.) into the ventricles of WT mice before the brains were collected $(n=6)$. The activity of microglia cells was determined by immunofluorescence. G. BV-2 cells were incubated with TNF- $\alpha$ for $24 \mathrm{~h}$. The expression of TNF- $\alpha$ was determined by qRT-PCR. H., I. TNF- $\alpha(10 \mathrm{ng} / 5 \mu \mathrm{l})$ was injected (i.c.v.) into the ventricles of WT mice before the brains were collected $(n=6)$. TNF- $\alpha$ immunoreactivity was revealed with an anti-TNF- $\alpha$ antibody. TNF- $\alpha$ protein and mRNA levels were determined by TNF- $\alpha$ enzyme immunoassay kits and qRT-PCR, respectively. J. D1A cells were treated with TNF- $\alpha$ $(10 \mathrm{ng} / \mathrm{ml})$ for $24 \mathrm{~h}$. ( $\mathrm{J}$ left panels) The activity of the TNF- $\alpha$ promoter was determined using luciferase activity kits. (J right panels) The binding activity of AP-1 to the promoter of TNF- $\alpha$ was determined by ChIP assay. K. The model of TNF- $\alpha$ origination. $*, p<0.05$ with respect to the vehicle-treated control. 
the TNF- $\alpha$ promoter (Figure $3 \mathrm{~K}$ ). To understand if the increased production of TNF- $\alpha$ resulted from astrocyte activation, we assessed the activity of astrocytes following i.c.v. injection of $\mathrm{PGE}_{2}$. The results demonstrated that astrocytes were markedly stimulated by $\mathrm{PGE}_{2}$ injection (Figure 3M).

To further understand the role of COX-2 metabolic products in TNF- $\alpha$ regulation, we similarly injected (i.c.v.) $\mathrm{PGI}_{2}$ into the ventricles of 6-month-old APP/PS1 mice. In contrast to $\mathrm{PGE}_{2}$ injection, $\mathrm{PGI}_{2}$ injection (i.c.v.) decreased the positive staining of TNF- $\alpha$ in the cerebral cortex of the APP/PS1 transgenic mice at 6 months of age (Figure 3I). mRNA and protein levels of TNF- $\alpha$ were assessed using qRT-PCR and western blotting. Results similar to those of the IHC assays were obtained (Figures 3J, Supplementary Figure 1B). Additionally, $\mathrm{PGI}_{2}$ treatment actively altered the transcriptional activity of the TNF- $\alpha$ promoter and the synthesis of TNF- $\alpha$ in live animals, as observed by live animal imaging (Figure 3L). We then sought to understand the role of $\mathrm{PGI}_{2}$ in regulating the expression of TNF- $\alpha$ through the activity of astrocyte by quantifying astrocytel activity following the injecting (i.c.v.) of $\mathrm{PGI}_{2}$. As expected, the activity of astrocyte cells was suppressed by $\mathrm{PGI}_{2}$ injection (i.c.v.) (Figure $3 \mathrm{~N}$ ). These observations not only demonstrated the opposing roles of $\mathrm{PGE}_{2}$ and $\mathrm{PGI}_{2}$ in regulating the expression of TNF- $\alpha$ but also indicated the possible roles of astrocyte in the expression of TNF- $\alpha$. To further confirm the important roles of astrocyte in the production of TNF- $\alpha, \mathrm{PGE}_{2}$ and $\mathrm{PGI}_{2}$ were used to treat D1A cells, and the results demonstrated that $\mathrm{PGE}_{2}$ treatment increased the expression of TNF- $\alpha$ and that $\mathrm{PGI}_{2}$ treatment decreased the expression of TNF- $\alpha$ in
A

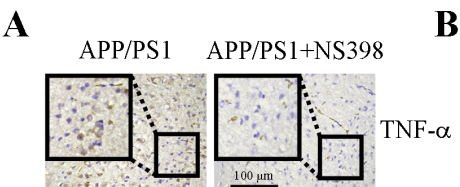

C

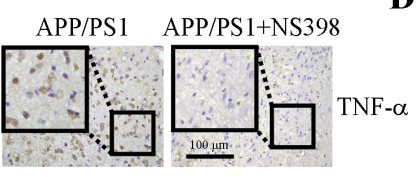

E

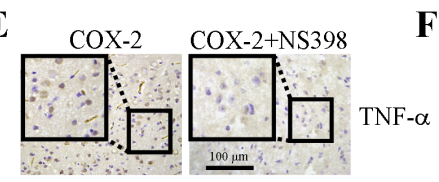

G

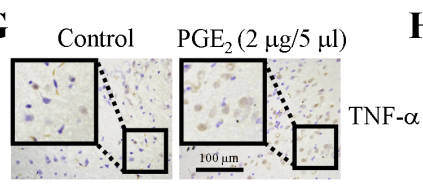

B

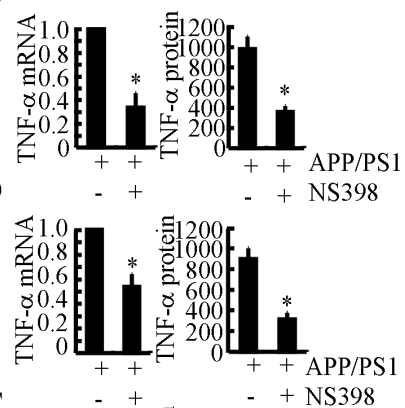

F $\quad-+\quad-+$ NS398

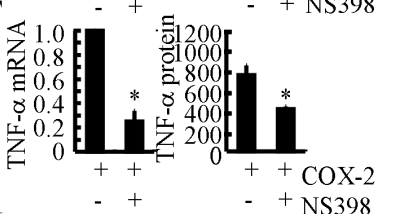

H

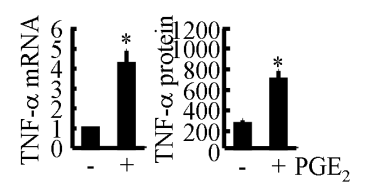

I
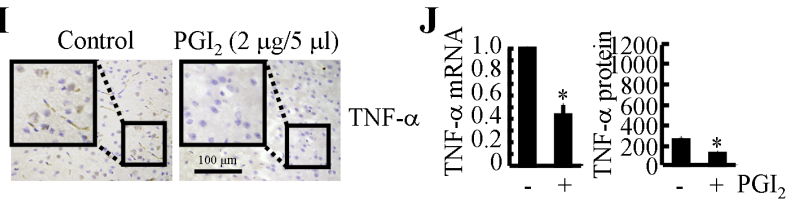

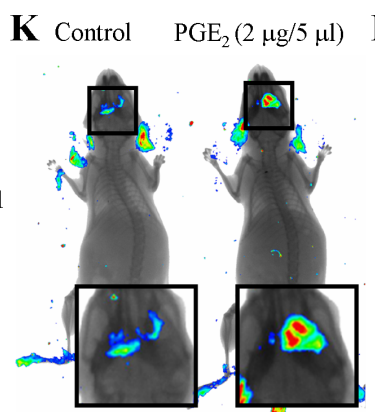

TNF- $\alpha$ promoter

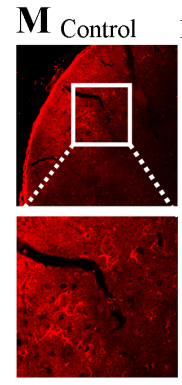

PGE
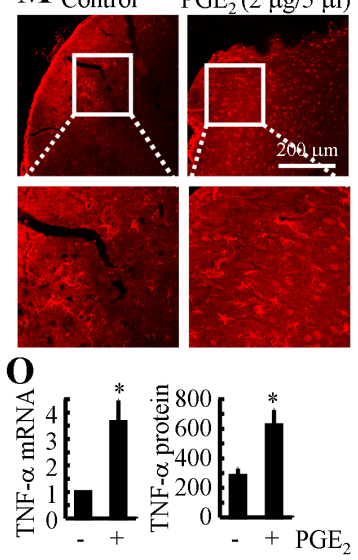

L Control $\mathrm{PGI}_{2}(2 \mu \mathrm{g} / 5 \mu \mathrm{l})$

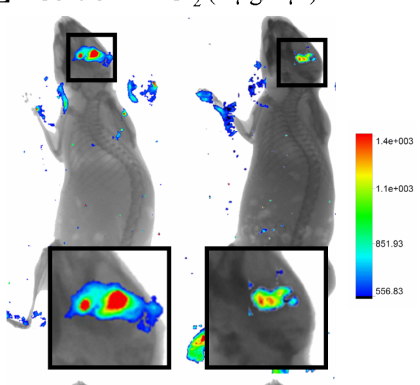

TNF- $\alpha$ promoter

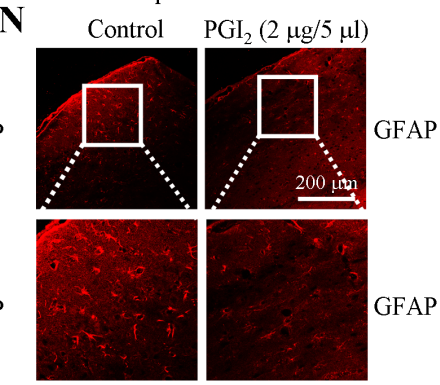

$\mathbf{P}$

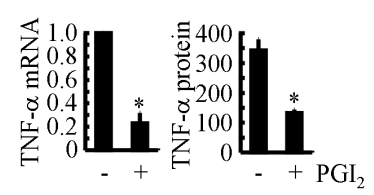

Figure 3: COX-2 mediated the opposing effects of PGE and PGI $_{2}$ in regulating the expression of TNF- $\alpha$ in APP/PS1 Tg mice. A., B. APP/PS1 or (E, F) COX-2 transgenic mice at the age of 3 months received NS398 (50 $\mu \mathrm{g} / 20 \mu \mathrm{l} / \mathrm{d})$ for 6 months before the brains were harvested $(n=6)$. C., D. The APP/PS1 mice were intracerebroventricularly (i.c.v.) injected with NS398 $(2 \mu \mathrm{g} / 5 \mu 1)$ for 24 $\mathrm{h}(n=6)$. In select experiments, the WT or APP/PS1 mice were injected (i.c.v.) with $\mathrm{PGE}_{2}$ G., H. or PGI $\mathbf{I}_{\text {., }} \mathbf{J}$., respectively, for $24 \mathrm{~h}(n=$ 6). A., C., E., G., I. TNF- $\alpha$ immunoreactivity was determined via immunohistochemistry with an anti-TNF- $\alpha$ antibody. B., D., F., H.,J.-L. TNF- $\alpha$ protein and mRNA levels were determined using TNF- $\alpha$ enzyme immunoassay kits and qRT-PCR, respectively. The total amount of protein and GAPDH served as internal controls. K. L. the cerebral ventricle in one hemisphere was injected with $\mathrm{PGE}_{2}(2 \mu \mathrm{g} / 5 \mu \mathrm{l})$ or $\mathrm{PGI}_{2}(2 \mu \mathrm{g} / 5 \mu \mathrm{l})$, and the cerebral ventricle on the other side was injected (i.c.v.) with D1A cells that had been pre-transfected with the TNF- $\alpha$ promoter $(n=4)$. Luciferase activity was measured in the different groups of mice using a live animal imaging system. M., N. the WT or APP/PS1 mice were injected (i.c.v.) with $\mathrm{PGE}_{2}$ or $\mathrm{PGI}_{2}$, respectively, for $24 \mathrm{~h}(n=6)$. GFAP immunofluorescence was revealed with an GFAP-specific antibody and observed under a microscope. O., P. D1A cells were treated with $\mathrm{PGE}_{2}$ or PGI for $24 \mathrm{~h}$ before total RNA was extracted. TNF- $\alpha$ enzyme immunoassay kits and qRT-PCR, respectively. The total amount of protein and GAPDH served as internal controls. ${ }^{*}, p<0.05$ with respect to the vehicle-treated control. 


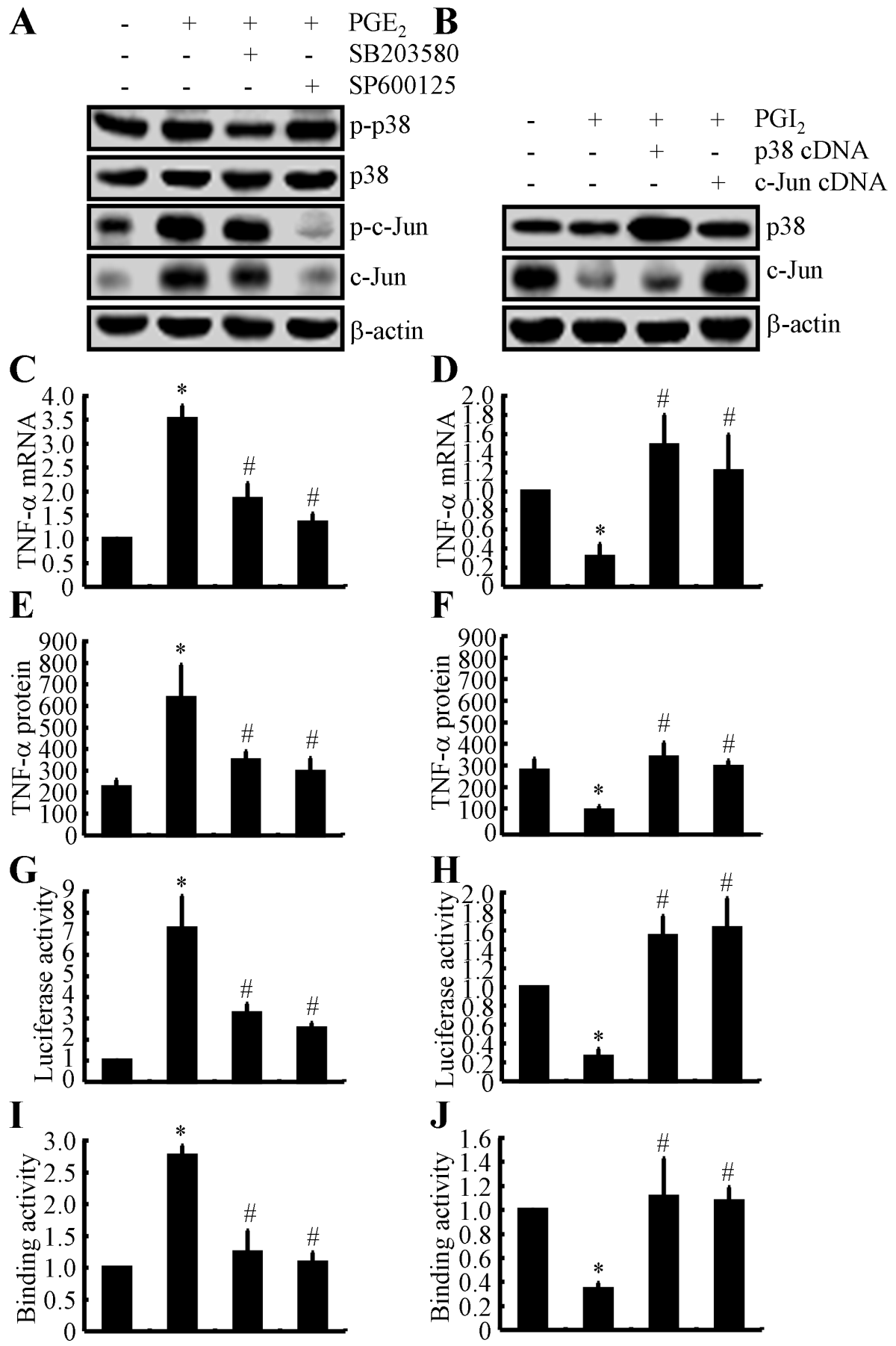

Figure 4: Critical role of the p38 and JNK/c-Jun pathways in regulating the expression of TNF- $\alpha$ in PGE Pand PGI- $_{2}$ treated D1A cells. A., C., E., G., I. Mouse D1A astrocyte were treated with $\mathrm{PGE}_{2}(10 \mu \mathrm{M})$ in the absence or presence of the p38 inhibitor SB203580 $(10 \mu \mathrm{M})$ or the JNK inhibitor SP600125 $(10 \mu \mathrm{M})$ for $24 \mathrm{~h}$ before protein or mRNA was extracted. A. Levels of phosphorylated p38, total p38, phosphorylated c-Jun and total c-Jun were detected by immunoblotting using specific antibodies. Equal lane loading was demonstrated by the similarity in the intensity of the band for total $\beta$-actin. C., E. TNF- $\alpha$ mRNA and protein levels were determined using TNF- $\alpha$ enzyme immunoassay kits and qRT-PCR, respectively. G. The activity of the TNF- $\alpha$ promoter was determined using a luciferase activity kit. I. The binding activity of AP-1 to the promoter of TNF- $\alpha$ was determined by ChIP assay. B., D., F., H., J. The D1A cells were pre-transfected with p38 or c-Jun cDNA before being treated with PGI $(10 \mu \mathrm{M})$ for $24 \mathrm{~h}$. B. Levels of total p38 and c-Jun were detected by immunoblotting using specific antibodies. Equal lane loading was demonstrated by the similarity in the intensity of the band for total $\beta$-actin. D., F. TNF- $\alpha$ mRNA and protein levels were determined using TNF- $\alpha$ enzyme immunoassay kits and qRT-PCR, respectively. H. The activity of the TNF- $\alpha$ promoter was determined using a luciferase activity kit. $\mathbf{J}$. The binding activity of AP- 1 to the promoter of TNF- $\alpha$ was determined by ChIP assay. The data represent the mean \pm S.E. of three independent experiments. ${ }^{*}, p<0.05$ with respect to the vehicletreated or vector-transfected control. \#, $p<0.05$ compared to treatment with $\mathrm{PGE}_{2}$-or $\mathrm{PGI}_{2}$ alone. 
D1A cells (Figures 3O, 3P). Thus, it is clear that COX2 overexpression in APP/PS1 Tg mice upregulates the expression of TNF- $\alpha$ via the antagonistic effects of $\mathrm{PGE}_{2}$ and $\mathrm{PGI}_{2}$ on the activity of astrocyte.

\section{The $\mathrm{p38}$ and $\mathrm{JNK} / \mathrm{c}-\mathrm{Jun}$ signalling pathways are} critical for mediating the effects of $\mathrm{PGE}_{2}$ and $\mathrm{PGI}_{2}$ in regulating the expression of TNF- $\alpha$ in astrocyte

Because $\mathrm{PGE}_{2}$ and $\mathrm{PGI}_{2}$ exhibited antagonistic effects on regulating the expression of TNF- $\alpha$, we next determined the mechanism of TNF- $\alpha$ regulation by $\mathrm{PGE}_{2}$ and $\mathrm{PGI}_{2}$. Using D1A cell cultures, we found that $\mathrm{PGE}_{2}$ treatment induced the phosphorylation of p38 without altering the total protein levels of p38 in D1A cells (Figure 4A). To further elucidate the potential role of $\mathrm{p} 38$ in regulating the expression of TNF- $\alpha$, we treated D1A cells with the pharmacological p38 inhibitor SB203580 $(10 \mu \mathrm{M})$ in the absence or presence of $\mathrm{PGE}_{2}(10 \mu \mathrm{M})$. Incubation of D1A cells with SB203580 (10 $\mu \mathrm{M})$ not only suppressed the $\mathrm{PGE}_{2}$-induced phosphorylation of p38 but also reversed the $\mathrm{PGE}_{2}$-dependent decrease in TNF- $\alpha$ synthesis (Figures 4C, 4E). Similar results were obtained when we treated D1A cells with the JNK inhibitor SP600125 $(10 \mu \mathrm{M})$ in the presence of PGE $_{2}(10$ $\mu \mathrm{M}$ ) (Figures $4 \mathrm{~A}, 4 \mathrm{C}, 4 \mathrm{E}$ ). In contrast to $\mathrm{PGE}_{2}$ treatment, $\mathrm{PGI}_{2}(10 \mu \mathrm{M})$ treatment decreased the phosphorylation of p38 and c-Jun, which resulted in TNF- $\alpha$ suppression in D1A cells (Figure 4B). When we overexpressed p38 and c-Jun in D1A cells, the levels of TNF- $\alpha$ were restored to basal levels (Figures 4B, 4D, 4F).

To identify the mechanism of the transcriptional upregulation of TNF- $\alpha$ by $\mathrm{PGE}_{2}$ and $\mathrm{PGI}_{2}$, we investigated the possible involvement of transcription factors in this process. In previous studies [23], AP1 was shown to be
A

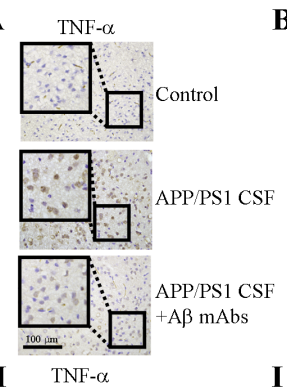

H
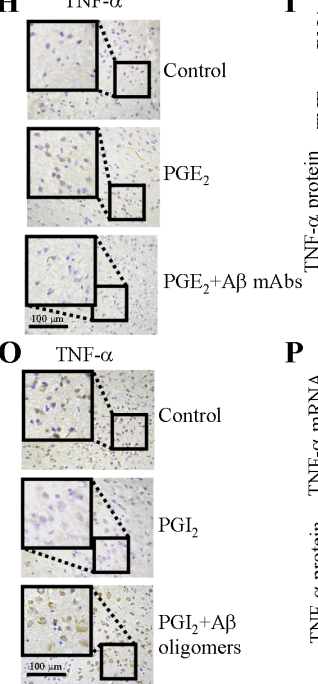

B

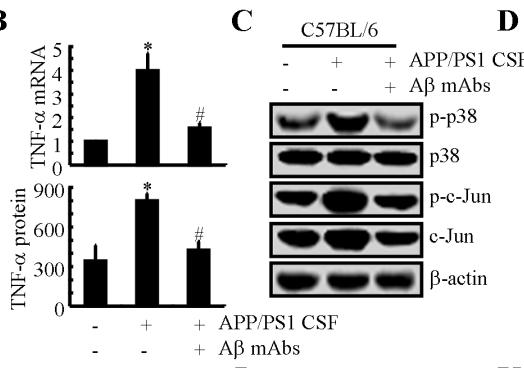

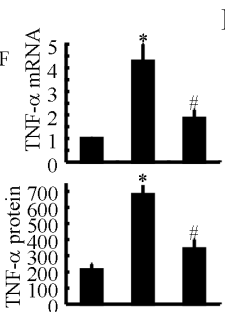

J $\quad$ C $57 \mathrm{BL} / 6$
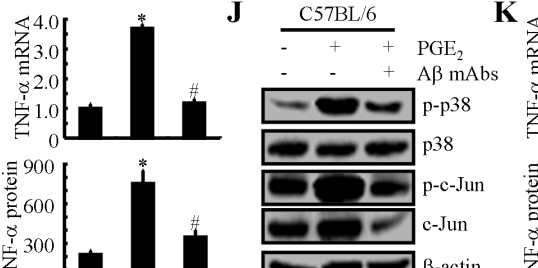

p-c-Jun
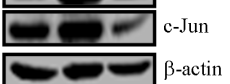

GE

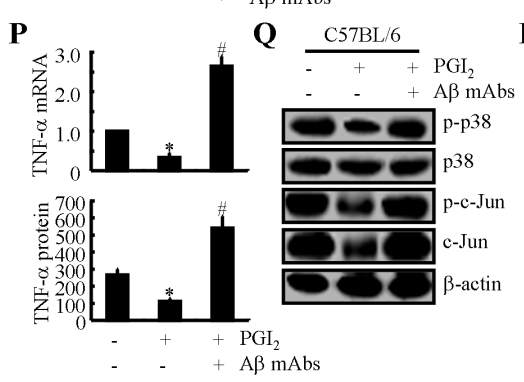

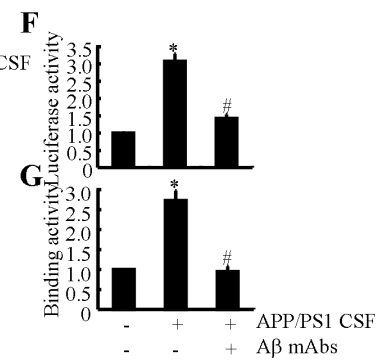

$\mathbf{E}$
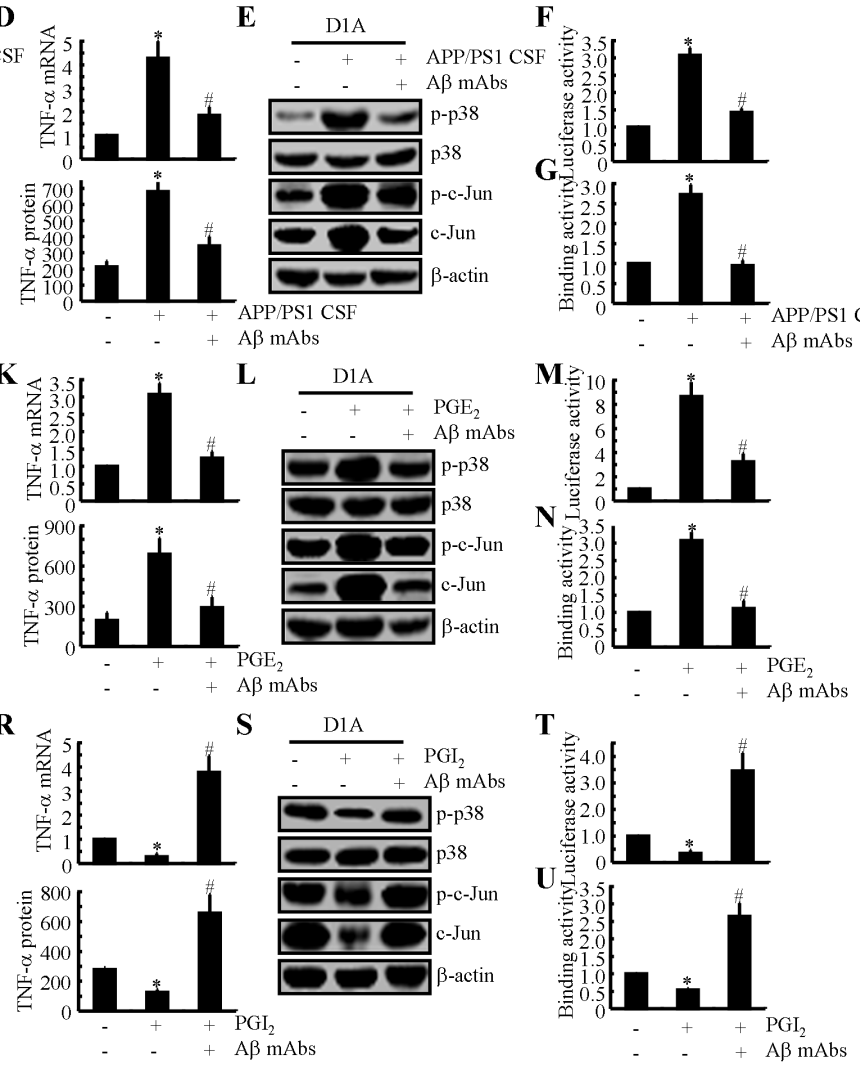

Figure 5: $A \beta_{1-42}$ mediated the antagonistic effects of $\mathrm{PGE}_{2}$ and $\mathrm{PGI}$ in regulating the expression of TNF- $\alpha$. A.-C. Cerebrospinal fluid (CSF) was collected from APP/PS1 mice at 6 months of age and then injected (i.c.v.) into WT C57BL/6 mice in the absence or presence of $A \beta$ antibodies $(1 \mu \mathrm{g} / 5 \mu \mathrm{l})$. After two weeks, the mice were sacrificed $(n=4)$. H.-J. The WT mice were injected with $\mathrm{PGE}_{2}(2 \mu \mathrm{g} / 5 \mu \mathrm{l})$ in the absence or presence of A $\beta$ antibodies $(1 \mu \mathrm{g} / 5 \mu \mathrm{l})$ for $24 \mathrm{~h}(n=6)$. O.-Q. The APP/PS1 mice were injected with $\mathrm{PGI}_{2}$ in the absence or presence of $\mathrm{A} \beta(1 \mu \mathrm{g} / 5 \mu \mathrm{l})$ for $24 \mathrm{~h}(n=6)$. D.-G., K.-N., R.-U. Similar treatments were applied to D1A cells. (A, H, O) TNF- $\alpha$ immunoreactivity was determined via immunohistochemistry. B., I., P., D., K., R. TNF- $\alpha$ protein and mRNA levels were determined by TNF- $\alpha$ enzyme immunoassay kits and qRT-PCR, respectively. C., J., Q., E., L., S. Levels of phosphorylated p38, total p38, phosphorylated c-Jun and total c-Jun were detected by immunoblotting using specific antibodies. Equal lane loading was demonstrated by the similarity in the intensity of the band for total $\beta$-actin. F., M., T. The activity of the TNF- $\alpha$ promoter was determined by luciferase activity kits. G., N., U. The binding activity of AP-1 to the promoter of TNF- $\alpha$ was determined by ChIP assay. ${ }^{*}, p<0.05$ with respect to the vehicle-treated control. \#, $p<0.05$ compared to treatment with $\mathrm{PGE}_{2}$ or $\mathrm{PGI}_{2}$ alone. 
involved in regulating the synthesis of TNF- $\alpha$. Consistent with these previous studies, we found that $\mathrm{PGE}_{2}$ and $\mathrm{PGI}_{2}$ regulated the luciferase activity of the TNF- $\alpha$ promoter in opposite directions (Figures 4G, 4H). In addition, these data were further confirmed using chromatin immunoprecipitation assays (Figures 4I, 4J). Therefore, these data provide concrete support for the notion that $\mathrm{PGE}_{2}$ and $\mathrm{PGI}_{2}$ have antagonistic effects on the regulation of TNF- $\alpha$ expression via a $\mathrm{p} 38$ - and JNK/c-Jun-dependent AP-1-activating mechanism.

\section{A $\beta$ production is involved in mediating the antagonistic effects of $\mathrm{PGE}_{2}$ and $\mathrm{PGI}_{2}$ in regulating the expression of TNF- $\alpha$ in the cerebral cortex of APP/PS1 Tg mice}

Due to the essential role of $A \beta_{1-42}$ in neuroinflammation $[5,6]$, we sought to determine the involvement of $A \beta_{1-42}$ in mediating the effects of $\mathrm{PGE}_{2}$ and $\mathrm{PGI}_{2}$ in regulating the expression of TNF- $\alpha$. To further understand the role of $A \beta_{1-42}$ in TNF- $\alpha$ regulation, we injected CSF from 6-month-old APP/PS1 mice age into WT mice in the absence or presence of an A $\beta$ antibody ( $1 \mu \mathrm{g} / 5 \mu \mathrm{l})$. After two weeks, the mice were sacrificed, and the expression of TNF- $\alpha$ was determined. Our data revealed that APP/PS1 CSF injection (i.c.v.) elevated the expression of TNF- $\alpha$ and that this elevation was blocked by the $\mathrm{A} \beta$ antibody, as revealed by immunohistochemistry (Figure 5A). mRNA and protein levels of TNF- $\alpha$ were assessed using qRT-PCR and western blotting, and these assays revealed results similar to those of the IHC assays (Figure 5B). In addition, the CSF of the APP/PS1 Tg mice had the ability to stimulate the phoshorylation of p38 and c-Jun in the WT mice, and this effect was reversed by the addition of the $\mathrm{A} \beta \mathrm{mAbs}$ (Figure $5 \mathrm{C}$ ). Similar results were also obtained in APP/PS1 CSF-treated D1A cells (Figures $5 \mathrm{D}, 5 \mathrm{E})$. Promoter and ChIP assays further verified that $\mathrm{A} \beta$ in the CSF of APP/PS1 mice has the ability to stimulate the transcriptional or translational activity of TNF- $\alpha$ in D1A cells (Figures 5F, 5G).

To further verify the above results, we injected (i.c.v.) $\mathrm{PGE}_{2}(2 \mu \mathrm{g} / 5 \mu \mathrm{l})$ into the ventricles of WT mice in the absence or presence of an $\mathrm{A} \beta_{1-42}$ antibody $(1 \mu \mathrm{g} / 5$ $\mu 1)$. The results demonstrated that the $A \beta_{1-42}$ antibody thoroughly diminished the stimulatory effects of $\mathrm{PGE}_{2}$ on TNF- $\alpha$ expression (Figures 5H, 5I). In addition, the phosphorylation of p38 and c-Jun was attenuated by the injection of $\mathrm{A} \beta \mathrm{mAbs}(1 \mu \mathrm{g} / 5 \mathrm{ml})$ for $24 \mathrm{~h}$ (Figure $5 \mathrm{~J}$ ). The observations were further confirmed in D1A cells (Figures $5 \mathrm{~K}-5 \mathrm{~N}$ ). In contrast to $\mathrm{PGE}_{2}$ treatment, $\mathrm{PGI}_{2}$ treatment showed inhibitory effects on TNF- $\alpha$ expression in APP/PS1 Tg mice (Figures 5O, 5P). When we added $\mathrm{A} \beta_{1-42}$ oligomers to the ventricles of APP/PS1 Tg mice, the levels of TNF- $\alpha$ were restored to basal levels (Figures $5 \mathrm{O}, 5 \mathrm{P})$. The $\mathrm{p} 38$ and c-Jun signalling pathways were once again involved in mediating TNF- $\alpha$ synthesis in the Tg mice (Figure 5Q). In line with these in vivo results, in vitro observations also supported this notion and confirmed the role of AP1 in mediating TNF- $\alpha$ synthesis (Figures 5R$5 \mathrm{U})$. Therefore, the production of $A \beta_{1-42}$ involved in the roles of $\mathrm{PGE}_{2}$ and $\mathrm{PGI}_{2}$ in regulating the expression of TNF- $\alpha$ in APP/PS1 Tg mice, an experimental AD model.

\section{Not only $A \beta_{1-42}$ oligomers but also $A \beta_{1-42}$ fibrils stimulate the expression of TNF- $\alpha$ in the brains of APP/PS1 mice}

Even though $\mathrm{PGI}_{2}$-induced $\mathrm{A} \beta_{1-42}$ could not alleviate TNF- $\alpha$ suppression in the cells, these observations indicate that $A \beta$ deposition might be critical for the TNF- $\alpha$ upregulation in the mice. To further validate this hypothesis, we injected $A \beta$ oligomers (i.c.v.) into the ventricles of WT mice. The results demonstrated that TNF- $\alpha$ expression was upregulated (Figures 6A, 6B). In addition, the phosphorylation of p38 and c-Jun was upregulated in the $\mathrm{A} \beta_{1-42}$ oligomer-injected mice (Figure $6 \mathrm{C})$. Consistent with the critical role of astrocyte in producing TNF- $\alpha$, injection (i.c.v.) of $A \beta_{1-42}$ oligomers into the ventricles of the WT mice stimulated the activity of GFAP (Figure 6D). In agreement with these in vivo observations, in vitro studies further verified the critical role of $A \beta_{1-42}$ oligomers in stimulating the expression of TNF- $\alpha$ in D1A cells (Figures 6E-6G).

Because TNF- $\alpha$ is progressively upregulated during the course of $\mathrm{AD}$ development, we sought to understand the role of $A \beta$ fibrils and APs in upregulating the expression of TNF- $\alpha$. To further explore the role of the advanced aggregate forms of $A \beta_{1-42}$ in TNF- $\alpha$ regulation, we sliced fresh brain specimens from WT mice $(400 \mu \mathrm{m})$ for culturing. The results demonstrated that TNF- $\alpha$ was activated after $24 \mathrm{~h}$ of treatment with $\mathrm{A} \beta_{1-42}$ fibrils (Figure $6 \mathrm{H})$. In addition, astrocyte activity was stimulated by the A $\beta$ fibril treatment (Figure 6I). Similar results were obtained in D1A cells (Figure 6J). To further elucidate the underlying mechanism, we conducted experiments to determine the effects of $A \beta$ fibrils on the activity of the p38 and c-Jun signalling pathways. The results demonstrated that the $A \beta$ fibrils stimulated the activity of the TNF- $\alpha$ promoter by activating AP1 in D1A cells (Figures 6K, 6L). Therefore, our data revealed that not only $A \beta_{1-42}$ oligomers but also $\mathrm{A} \beta_{1-42}$ fibrils have the ability to stimulate TNF- $\alpha$ expression by activating astrocyte, which produce high levels of TNF- $\alpha$ during the course of AD development.

\section{TNF- $\alpha$ overproduction accelerates the development of $\mathrm{AD}$}

Because the mechanisms underlying the induction of TNF- $\alpha$ during the course of AD development in APP/PS1 mice had been elucidated, we decided to investigate the 


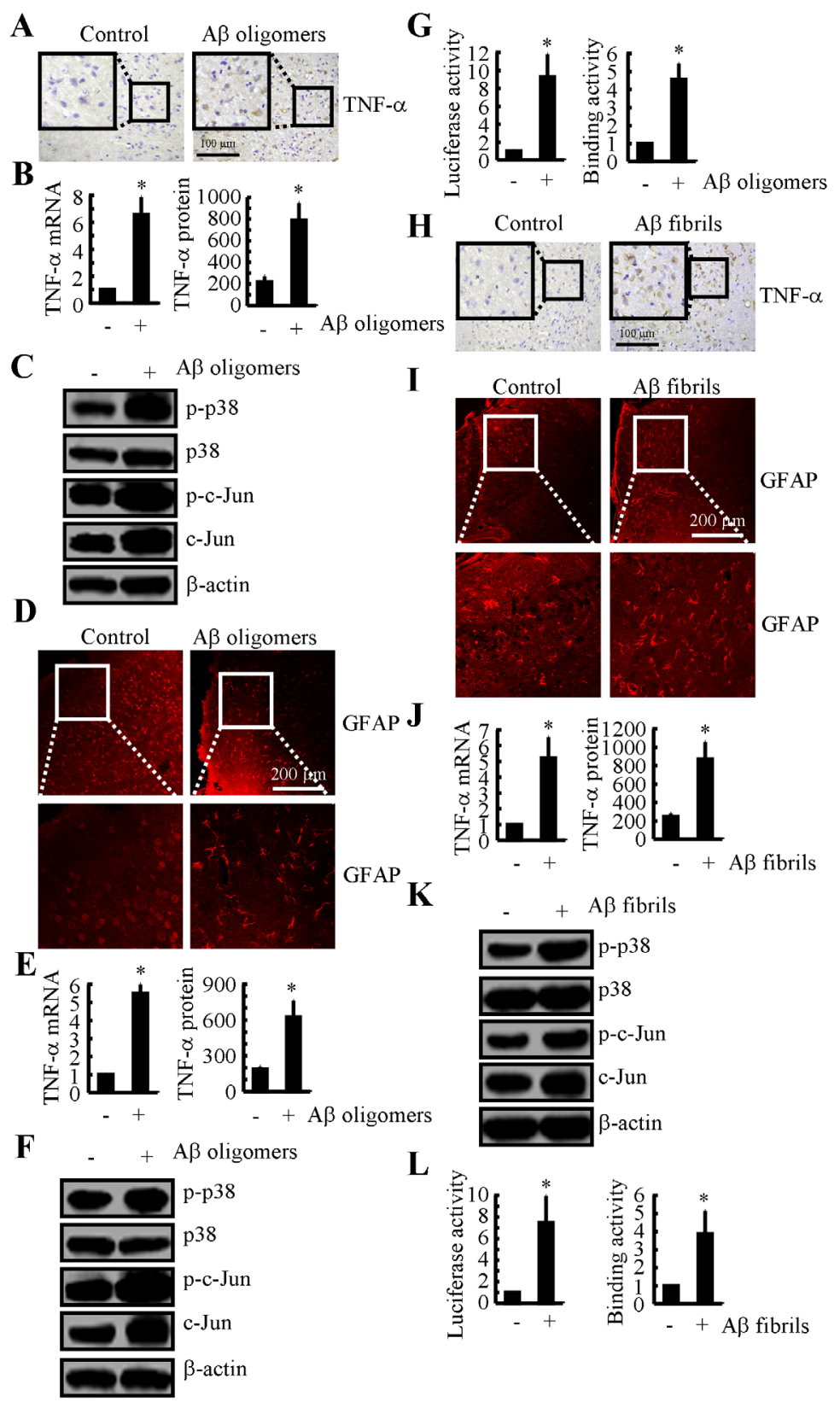

Figure 6: Both $A \beta$ oligomers and fibrils have the ability to stimulate the expression of TNF- $\alpha$ by activating astrocyte via a p38- and c-Jun-dependent pathway. A.-D. WT mice at the age of 3 months were injected with A $\beta$ oligomers $(1 \mu \mathrm{g} / 5 \mu \mathrm{l})$ for 24 $\mathrm{h}$ before the brains were harvested $(n=6)$. A. TNF- $\alpha$ immunoreactivity was determined via immunohistochemistry. B. TNF- $\alpha$ protein and mRNA levels were determined by TNF- $\alpha$ enzyme immunoassay kits and qRT-PCR, respectively. C. Levels of phosphorylated p38, total p38, phosphorylated c-Jun and total c-Jun were detected by immunoblotting using specific antibodies. Equal lane loading was demonstrated by the similarity of the intensity of the bands for total $\beta$-actin. D. The activity of astrocyte was determined by immunofluorescence. E.-G. D1A cells were treated with $\mathrm{A} \beta$ oligomers $(1 \mu \mathrm{M})$ for 24 before the total mRNA and protein was extracted. E. TNF- $\alpha$ protein and mRNA levels were determined by TNF- $\alpha$ enzyme immunoassay kits and qRT-PCR, respectively. F. Levels of phosphorylated p38, total p38, phosphorylated c-Jun and total c-Jun were detected by immunoblotting using specific antibodies. Equal lane loading was demonstrated by the similarity of the intensity of the bands for total $\beta$-actin. G. The activity of the TNF- $\alpha$ promoter was determined by luciferase activity kits. The binding activity of AP- 1 to the promoter of TNF- $\alpha$ was determined by ChIP assay. H., I. Freshly sliced tissue was cultured with A $\beta$ fibrils $(1 \mu \mathrm{g} / \mathrm{ml})$ for $24 \mathrm{~h}$ before immunostaining with TNF-a or GFAP antibody. J.-L. D1A cells were treated with A $\beta$ fibrils for $24 \mathrm{~h}$ before total mRNA and protein was extracted. J. TNF- $\alpha$ protein and mRNA levels were determined by TNF- $\alpha$ enzyme immunoassay kits and qRT-PCR, respectively. K. Levels of phosphorylated p38, total p38, phosphorylated c-Jun and total c-Jun were detected by immunoblotting using specific antibodies. Equal lane loading was demonstrated by the similarity of the intensity of the bands for total $\beta$-actin. $\mathbf{L}$. The activity of the TNF- $\alpha$ promoter was determined by luciferase activity kits. The binding activity of AP-1 to the promoter of TNF- $\alpha$ was determined by ChIP assay. *, $p<0.05$ with respect to the vehicle-treated control. 
role of TNF- $\alpha$ in A $\beta$ deposition. The results demonstrated that intranasally administering TNF- $\alpha(10 \mathrm{ng} / 20 \mu \mathrm{l} / \mathrm{d})$ for 7 days clearly increased the expression of BACE-1, PS1 and PS2 and that these increases resulted in an acceleration of the production of $\mathrm{A} \beta_{1-42}$ (Figure 7A). This in vivo observation was further verified in $n 2$ a cells (Figure 7B). To further explore the role of TNF- $\alpha$ in $\mathrm{A} \beta$ aggregation, we further treated 3-month-old APP/PS1 mice for 3 months or 6 months. The results demonstrated that $A \beta$ deposition in APs was clearly elevated after 3 or 6 months of treatment (Figures 7C-7F). These observations clearly demonstrated that TNF- $\alpha$ overproduction accelerated the production and aggregation of $A \beta_{1-42}$ in APs, which exacerbate the development of AD.

When considered together, our data revealed that $\mathrm{PGE}_{2}$ stimulated the synthesis of TNF- $\alpha$ via an $\mathrm{A} \beta$ dependent, AP-1 activation-mediated pathway in APP/ PS1 Tg mice, an experimental AD model. Additionally, $\mathrm{PGI}_{2}$ attenuated the effects of $\mathrm{PGE}_{2}$ in stimulating the expression of TNF- $\alpha$ by decreasing the activity of the p38 and JNK/c-Jun pathways. Although $\mathrm{PGI}_{2}$ could upregulate the production of $\mathrm{A} \beta_{1-42}$, the induced $\mathrm{A} \beta_{1 \text {. }}$
${ }_{42}$ could not reverse the inhibitory effects of $\mathrm{PGI}_{2}$ on TNF- $\alpha$ expression. In line with these in vitro and in vivo observations, TNF- $\alpha$ was further found to be responsible for accelerating the production and deposition of $A \beta_{1-42}$. More importantly, both $A \beta_{1-42}$ oligomers and $A \beta_{1-42}$ fibrils had the ability to stimulate the expression of TNF- $\alpha$, which could potentially aggravate the pathogenesis of $\mathrm{AD}$ by accelerating $A \beta$ deposition in APs.

\section{DISCUSSION}

Prior work has revealed the early induction of COX-2 and of its metabolic products during the course of $\mathrm{AD}$ development [1]. Therefore, we studied the role of COX-2 and its metabolic products in AD. As a powerful inducer of inflammation, COX-2 has been shown to induce the expression of TNF- $\alpha$ via its metabolic products $[13,14]$. So, we investigated the role of $\mathrm{PGE}_{2}$ and $\mathrm{PGI}_{2}$ in regulating the expression of TNF- $\alpha$ during the course of $\mathrm{AD}$ development. Specifically, $\mathrm{PGE}_{2}$ stimulated the expression of TNF- $\alpha$ via an $\mathrm{A} \beta_{1-42}$-dependent, AP1activating pathway. In contrast, $\mathrm{PGI}_{2}$ attenuated the effects
A

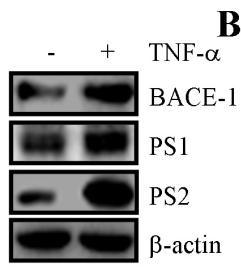

B
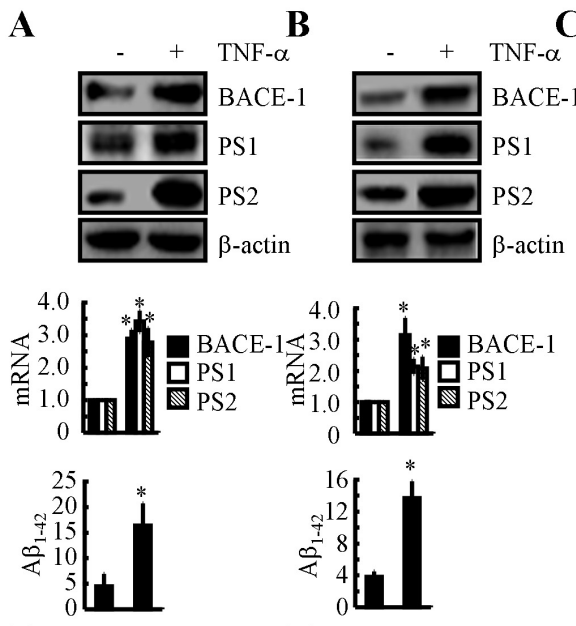

$\mathbf{E}$
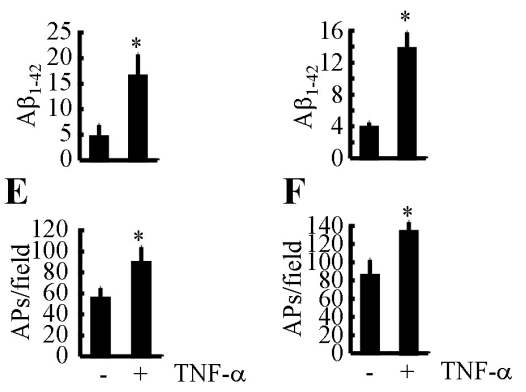
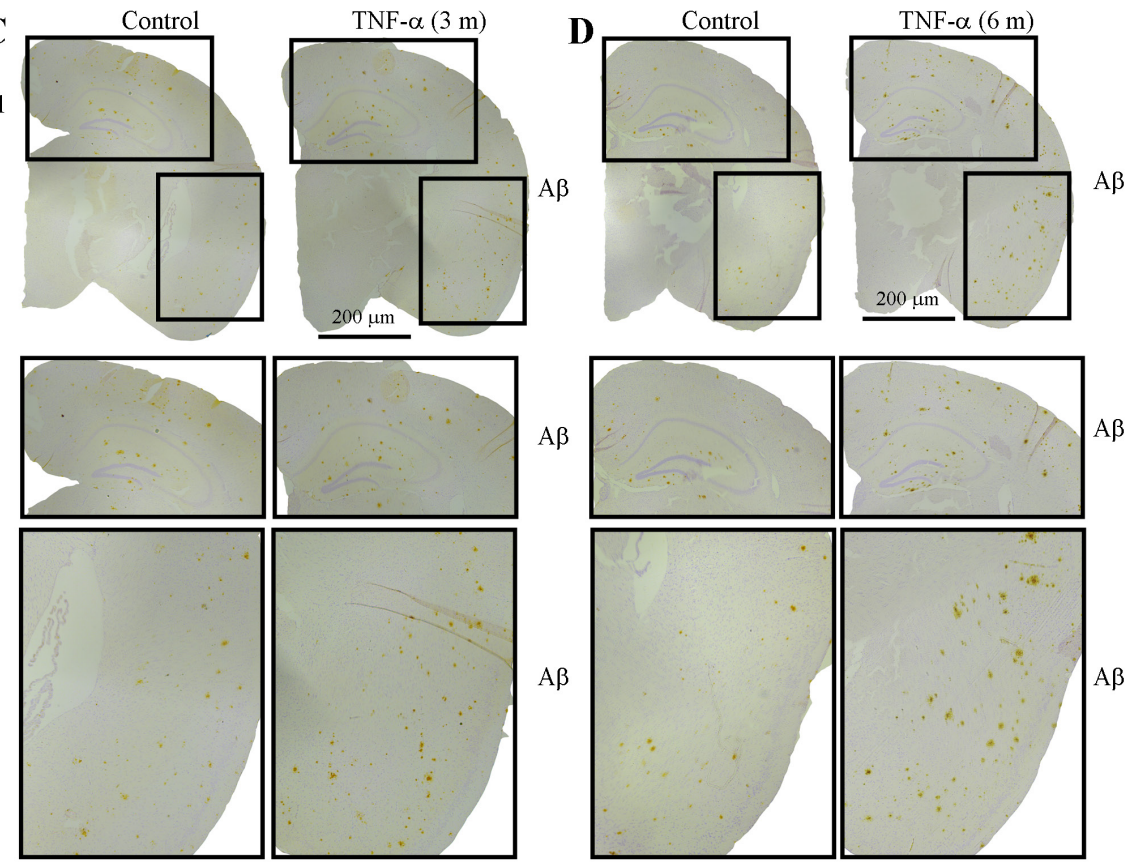

Figure 7: Intranasal administration of TNF- $\alpha$ accelerates A $\beta$ deposition in APs by inducing the expression of BACE-1, PS1 and PS2 during the course of AD development. A. TNF- $\alpha(10 \mathrm{ng} / 20 \mu \mathrm{l} / \mathrm{d})$ was nasally administered to 3-month-old WT mice for 7 days $(n=10)$. The protein and mRNA expression of BACE-1, PS1 and PS2 were determined by western blot and qRT-PCR. The total amounts of $\beta$-actin and GAPDH served as internal controls. The production of $A \beta_{1-42}$ was determined by western blot and $A \beta_{1-42}$ enzyme immunoassay kits. B. n2a cells were treated with TNF- $\alpha(10 \mathrm{ng} / \mathrm{ml})$ for $24 \mathrm{~h}$ before total mRNA and protein was extracted. The protein and mRNA expression of BACE-1, PS1 and PS2 were determined by western blot and qRT-PCR. The total amounts of $\beta$-actin and GAPDH served as internal controls. The production of $A \beta_{1-42}$ was determined by western blot and $A \beta_{1-42}$ enzyme immunoassay kits. C.-F. 3-monthold APP/PS1 mice were nasally administered TNF- $\alpha(10 \mathrm{ng} / 20 \mu \mathrm{l} / \mathrm{d})$ for 3 or 6 months before A $\beta$ deposition in APs was determined $(n=6)$. C., D. A $\beta$ immunoreactivity was determined using an immunohistochemistry assay. E., F. APs/field in the cerebral cortex and hippocampus of APP/PS1 mice were analysed by counting the number of APs in images of the immunohistochemically stained tissue. $*, p<0.05$ with respect to the vehicle-treated control. 
of $\mathrm{PGE}_{2}$ on inducing the expression of TNF- $\alpha$ via a $\mathrm{p} 38$ and $\mathrm{JNK} / \mathrm{c}$-Jun-activating mechanism. Although $\mathrm{A} \beta_{1-42}$ reliably induced the expression of TNF- $\alpha$ by activating p38 and $\mathrm{JNK} / \mathrm{c}$-Jun, $\mathrm{PGI}_{2}$-induced $\mathrm{A} \beta_{1-42}$ might not be sufficient to reverse the inhibitory effects of $\mathrm{PGI}_{2}$. In agreement with these in vitro observations, we found that $\mathrm{PGE}_{2}$ and $\mathrm{PGI}_{2}$ antagonistically regulated the expression of TNF- $\alpha$ in an A $\beta_{1-42}$-dependent manner. Moreover, both $\mathrm{A} \beta_{1-42}$ oligomers and $\mathrm{A} \beta$ fibrils had the ability to upregulate the expression of TNF- $\alpha$, resulting in constitutively high levels of TNF- $\alpha$ during the course of AD development.

Accumulating evidence has demonstrated that $\mathrm{PGI}_{2}$ has the ability to suppress the expression of TNF- $\alpha$. For instances, Vicil et al. [24] reported that TNF- $\alpha$ synthesis was inhibited by the PGI $_{2}$ analogue beraprost sodium in lipopolysaccharide (LPS)-treated lung alveolar epithelial cells. In line with this observation, Yeh et al. [25] found that $\mathrm{PGI}_{2}$ analogues, including iloprost and treprostinil, suppressed LPS-induced TNF- $\alpha$ expression in human monocyte-derived dendritic cells. In addition, the inhibitory effects of $\mathrm{PGI}_{2}$ on TNF- $\alpha$ expression have also been confirmed in human monocytes [26], endothelial cells [27] and diabetic patients [28]. Along these lines, our data not only identified a suppressive role of $\mathrm{PGI}_{2}$ in the expression of TNF- $\alpha$ but also provided the first demonstration that $\mathrm{PGI}_{2}$ attenuated the effects of $\mathrm{PGE}_{2}$ in stimulating the expression of TNF- $\alpha$. More importantly, the effects of $\mathrm{PGI}_{2}$ might be responsible for the cause for the failure of clinical trials for COX-2-specific inhibitors because these trials did not take into consideration the suppressive effects of $\mathrm{PGI}_{2}$ on the neuroinflammation of AD.

In view of the roles of $\mathrm{PGE}_{2}$ and $\mathrm{PGI}_{2}$ in regulating the production of $A \beta_{1-42}$ [29], possible involvements of $\mathrm{A} \beta_{1-42}$ in mediating the regulatory effects of $\mathrm{PGE}_{2}$ and $\mathrm{PGI}_{2}$ on the expression of TNF- $\alpha$ are hypothesized. Although, to the best of our knowledge, there are no related reports concerning the role of $\mathrm{PGE}_{2}$ in upregulating the expression of TNF- $\alpha$ via $\mathrm{A} \beta_{1-42}$, the effect of $\mathrm{PGE}_{2}$ in increasing the ratio of $\mathrm{A} \beta_{1-42}$ and $\mathrm{A} \beta_{1-40}$ has been demonstrated in HEK293 cells, SH-SY5Y cells and APP23 mice [30]. In agreement with this result, EP4 overexpression in APP/ PS1 Tg mice enhances the effect of $\mathrm{PGE}_{2}$ in increasing the ratio of $A \beta_{1-42}$ and $A \beta_{1-40}$ [10]. In addition, $\mathrm{PGE}_{2}$ treatment increases the production of $\mathrm{A} \beta_{1-42}$ in $\mathrm{C} 57 \mathrm{BL} / 6$ mice [31]. More closely, mPGES-1 overexpression in Tg2576 mice accelerated the deposition of $\mathrm{A} \beta_{1-42}$ in APs [32]. For PGI, it is also effective on stimulating the production of $\mathrm{A} \beta_{1-42}$ [29].

In line with the above observations, our data revealed that not only $A \beta_{1-42}$ oligomers but also $A \beta_{1-42}$ fibrils had ability to stimulate the expression TNF- $\alpha$. In agreement with our data, Liu et al. [33] reported that $\mathrm{A} \beta_{1 \text {. }}$ ${ }_{42}$ has the ability to stimulate the synthesis of TNF- $\alpha$ in rat hippocampus. This observation was further confirmed by Lv et al. [34], who suggested that the RAGE signalling pathway is important for TNF- $\alpha$ synthesis in $A \beta_{1-42}$-treated BV-2 cells. In addition, peripheral administration of an anti-TNF- $\alpha$ receptor fusion protein counteracted the $\mathrm{A} \beta_{25-}$ 35 -induced elevation of TNF- $\alpha$ and memory deficits in mice [35], suggesting that TNF- $\alpha$ acts downstream of A $\beta$ to impair the learning ability of mice during the course of $\mathrm{AD}$ development. Because $\mathrm{A} \beta_{25-35}$ is the minimum unit of $\mathrm{A} \beta$ involved in the pathogenesis of $\mathrm{AD}$, the injection of $\mathrm{A} \beta_{25-35}$ has been used to induce the expression of TNF- $\alpha$ in the astrocyte of the rat brain as an experimental model of $\mathrm{AD}[36,37]$. As expected, $\mathrm{A} \beta_{1-42}$ also induces the expression of TNF- $\alpha$ in AD experimental models [33]. However, these observations do not address the different aggregated forms of $A \beta$ in the regulation of the synthesis of TNF- $\alpha$. For example, Lv et al. [34] reported that $A \beta_{1-42}$ oligomers have the ability to stimulate the expression of TNF- $\alpha$ in BV-2 cells. Like $A \beta_{1-42}$ oligomers, fibrillar $A \beta_{1-42}$ also has the ability to activate microglia, which potentially contribute to the pathogenesis of AD [38]. In addition, Veerhuis et al. [39] demonstrated that AP-associated proteins, including $\mathrm{Clq}$ and $\mathrm{SAP}$, have the ability to enhance the effects of $A \beta_{1-42}$ in inducing the expression of TNF- $\alpha$ in adult human microglia. Compared to $A \beta_{1-42}$ fibrils, $A \beta_{1-42}$ oligomers exerted a more potent effect on the expression of TNF- $\alpha$ in rat brain [40]. These phenomena were explained by Lindberg et al. [41], who suggested that the structure of $A \beta$ determines the nature of the cytokines that are released from rat microglia. Notably, this theory was further supported by White et al. [42], who suggested that the high levels of IL-1 $\beta$ that are induced by $A \beta$ oligomers decrease over time, whereas $A \beta$ fibrils induce high levels of IL- $1 \beta$ that are sustained over time. Along these lines, we could not exclude the possibility that $\mathrm{A} \beta$ oligomers have the ability to initiate the synthesis of TNF- $\alpha$ during the early stage of AD and that $\mathrm{A} \beta$ fibrils are responsible for sustaining high levels of TNF- $\alpha$ during the late stage of $\mathrm{AD}$.

Although the above observations aquiescenced that microglia are the major source of TNF- $\alpha$ in primary cultured glials [43], they still could not negate the roles of astrocytes in producing TNF- $\alpha$ in primary cultured astrocytes [44]. Indeed, we extended the prior works to find that astrocytes are responsible for bridging the connections between $A \beta$ and microglia in stimulating the expression of TNF- $\alpha$. In line with our work [44], Choi et al. [45] recently reported that activated, but not non-activatedastrocytes are responsible for the synthesis of TNF- $\alpha$, which acts as a molecular coordinator of neuron-glia communication. This observation was further supported by previous study showing that TNF- $\alpha$ expression was stimulated in lipopolysaccharide (LPS)-, interferon $\gamma$ (IFN $\gamma$ )- or IL-1 $\beta$-stimulated astrocytes [46]. Lau et al. [47] also reported that TNF- $\alpha$ expression was also induced in traumatic and metabolic injury-activated brains. Since TNF- $\alpha$ was produced from both astrocytes and microglia in response to multiple stimulators, we further found 
that TNF- $\alpha$ is a molecular coordinator for mediating astrocytes and microglia communication. In another word, the microglia will produce TNF- $\alpha$ once astrocytes were activated and produced TNF- $\alpha$. Reciprocally, astrocytes will produce TNF- $\alpha$ once microglia were activated and produced TNF- $\alpha$. In addition, TNF- $\alpha$ was also identified to be expressed in primary cultured neurons. Even though TNF- $\alpha$ mediated the crosstalk between astrocytes and microglia, TNF- $\alpha$ neither exerts its biological function on astrocytes nor microglia. Interestingly, we found that TNF- $\alpha$ will translocate from astrocytes and microglia to neurons, which aggravate the neuroinflammation during the course of AD development and progression.

However, TNF- $\alpha$ is not passively involved in the development of AD. Consequently, our results demonstrated that TNF- $\alpha$ treatment accelerated the deposition of $A \beta_{1-42}$ in APs by inducing the expression of BACE- 1 and PS1/2 during the course of AD progression. Consistent with our findings, TNF- $\alpha$ was shown to have the ability to increase the expression of BACE- 1 in APPsw Tg mice [20]. In addition, TNF- $\alpha$ stimulated the $\gamma$-cleavage of APP in HEK293 cells [18]. Indeed, TNF- $\alpha$ has the ability to induce the expression or phosphorylation of $\gamma$-secretases, including PS1, PS2 and NCT, in HEK293 and human neuronal cells $[17,19]$. More directly, TNF- $\alpha$ plus IFN $\gamma$ has been shown to induce the production of $A \beta$ in human neuronal and extraneuronal cells [48]. A TNF- $\alpha$ inhibitor, 3,6'-dithiothalidomide, has been shown to block the effects of $A \beta_{1-42}$ on the memory deficits of mice [49]. When considered together, these data clearly reveal the reciprocal roles of TNF- $\alpha$ on the induction of $A \beta$, which further aggravates AD.

Regarding the mechanism, we found that the p38 and AP-1 pathways are involved in mediating the antagonistic regulatory effects of $\mathrm{PGE}_{2}$ and $\mathrm{PGI}_{2}$ on the expression of TNF- $\alpha$ in D1A cells. In agreement with our observations, accumulating evidence indicates that the p38 and JNK/c-Jun pathways are involved in the regulation of the expression of TNF- $\alpha$. However, although investigators tried to identify the mechanisms responsible for the suppression of the expression of TNF- $\alpha$ in astrocyte, this work did not extend to $\mathrm{PGE}_{2}$ and $\mathrm{PGI}_{2}$ [50-54]. This is not the first time we have demonstrated the involvement of the p38 and JNK/c-Jun pathways in regulating the expression of TNF- $\alpha$; however, we extended these mechanisms to include the roles of $\mathrm{PGE}_{2}$ and $\mathrm{PGI}_{2}$ in regulating the synthesis of TNF- $\alpha$. Nevertheless, we will not continue to discuss this mechanism. To keep the discussion focused, we though it was necessary to identify the cells that secreted TNF- $\alpha$. According to our data, TNF- $\alpha$ seemed to be secreted from astrocyte, which then bind to neurons to exert their biological functions. In agreement with our findings, Frey et al. [55] reported that TNF- $\alpha$ was significantly induced in LPStreated BV-2 cells. In line with this in vitro observation, our in vivo results further supported the notion that the deposition of $A \beta$ activates astrocyte. Activated microglia elicit the expression of TNF- $\alpha$, which influences the surrounding brain tissue [56]. More specifically, Clausen et al. [57] showed that $\mathrm{CD} 11 \mathrm{~b}^{+} \mathrm{CD} 45^{\mathrm{dim}}$ microglia are responsible for the synthesis of TNF- $\alpha$. Because TNF- $\alpha$ was highly expressed in astrocyte, the question of why our TNF- $\alpha$ immunostaining results seemed to show expression in neurons could be easily raised. Our results demonstrated that TNF- $\alpha$ secreted from astrocyte will bind to the receptors of microglia and neurons to exert its biological functions. In line with our data, the results of Bhaskar et al. [58] also suggested that microglia-derived TNF- $\alpha$ drives AD-related neuronal cell cycle events. Taken together, these observations not only more clearly delineate the mechanism responsible for the upregulation of TNF- $\alpha$ during the course of AD development but also provide insight into the opposing roles of $\mathrm{PGE}_{2}$ and $\mathrm{PGI}_{2}$ in the learning ability of AD experimental model mice via their effects on TNF- $\alpha$. More importantly, we identify a possible reason for the failure of clinical studies of COX2-specific inhibitors by showing that the ratio of $\mathrm{PGE}_{2}$ to $\mathrm{PGI}_{2}$ is important for the pathogenesis of $\mathrm{AD}$. If the COX-2-specific inhibitors could not return the imbalance between $\mathrm{PGE}_{2}$ and $\mathrm{PGI}_{2}$ to a physiological level, they could not produce a therapeutic effect against AD.

In conclusion, this study provides new evidence for the antagonistic roles of $\mathrm{PGE}_{2}$ and $\mathrm{PGI}_{2}$ in regulating the expression of TNF- $\alpha$ in vitro and in vivo. Specifically, we showed that $\mathrm{PGE}_{2}$ upregulates the expression of TNF- $\alpha$ via an A $\beta$-dependent, p38- and JNK/c-Jun-activating pathway. In contrast, we showed that $\mathrm{PGI}_{2}$ attenuates the effects of $\mathrm{PGE}_{2}$ in stimulating the expression of TNF- $\alpha$. Because $\mathrm{PGI}_{2}$ only modestly induced $\mathrm{A} \beta_{1-42}$, the resulting $\mathrm{A} \beta_{1-42}$ induction was insufficient to alleviate the cells from $\mathrm{PGI}_{2}-$ mediated TNF- $\alpha$ inhibition in an AP1-dependent manner. With regard to the critical role of $A \beta_{1-42}$ in regulating the expression of TNF- $\alpha$, we further discovered that $A \beta_{1-42}$ oligomers and fibrils are responsible for the synthesis of TNF- $\alpha$ during the early and late stages of AD, respectively. Reciprocally, TNF- $\alpha$ binds to the receptors of neurons to aggravate $\mathrm{AD}$ by accelerating the deposition of $\mathrm{A} \beta_{1-42}$ in APs via the upregulation of the expression of BACE-1 and PS1/2. These findings provide new insight into the mechanisms of TNF- $\alpha$ regulation in the brain during the course of AD development.

\section{MATERIALS AND METHODS}

\section{Reagents}

$\mathrm{PGI}_{2}, \mathrm{PGE}_{2}, \mathrm{~A} \beta_{1-42}$ and the inhibitors NS398, SB203580, and SP600125 were obtained from SigmaAldrich Corp (St. Louis, MO, USA). Antibodies against $\beta$-actin, p38, p-p38, c-Jun, p-c-Jun, COX-2, TNF- $\alpha$, 
BACE-1, PS1, PS2, Iba1, GFAP, NeuN and A $\beta$ were purchased from Cell Signaling Technology, Inc. (Danvers, MA, USA). The mouse TNF- $\alpha$ enzyme immunoassay kits were obtained from Raybiotech, Inc. (Norcross, GA, USA). The mouse $\mathrm{A} \beta_{1-42}$ enzyme immunoassay kits were obtained from Invitrogen (Carlsbad, CA, USA). Dual luciferase reporter assay kits were purchased from Promega (Beijing, P. R. China). The chromatin immunoprecipitation (ChIP) EZ-ChIP kit was purchased from Merck Millipore (Beijing, P. R. China). All reagents for the qRT-PCR and SDS-PAGE experiments were purchased from Bio-Rad Laboratories. All other reagents were from Invitrogen (Carlsbad, CA, USA) unless otherwise specified.

\section{Cell culture}

Mouse astrocyte D1A or microglia BV-2 cells were grown $\left(37{ }^{\circ} \mathrm{C}\right.$ and $\left.5 \% \mathrm{CO}_{2}\right)$ on 6 -cm tissue culture dishes $\left(10^{6}\right.$ cells per dish) in appropriate medium. In a select set of experiments, the cells were grown in serum-free medium for an additional $24 \mathrm{~h}$ before incubation with inhibitors in the absence or presence of $\mathrm{PGI}_{2}$ or $\mathrm{PGE}_{2}$, as previously described [59]. In separate experiments, D1A cells were cocultured with neuroblastoma $2 \mathrm{a}$ (n2a) cells or the cultured slices of mouse brains before determining the expression of TNF- $\alpha$ by immunostaining. In brief, D1A cells were seeded in the upper chamber of transwell and $\mathrm{n} 2 \mathrm{a}$ or cultured slices were cultured in the lower chamber of transwell. After $24 \mathrm{~h}$, the n2a or slices were immunostained with TNF- $\alpha$.

\section{Transgenic mice}

The wild type (WT), APP/PS1 transgenic mice [B6C3-Tg (APPswe, PSEN1dE9) 85Dbo/J (Stock Number: 004462)] or COX-2 transgenic mice (Stock Number 010703) were obtained from The Jackson laboratory (Bar Harbor, ME, USA). Genotyping was performed at 3-4 weeks after birth. The mice were housed in a controlled environment under a standard room temperature, relative humidity and 12-h light/dark cycle with free access to food and water. Mice were randomly separated into several groups and each group contains 10 mice for treatment. The general health and body weights of animals were monitored every day. The brains of animals from the different groups were collected under anesthesia and perfusion as previously described $[60,61]$.

\section{Intracerebroventricular injection (i.c.v)}

NS398, $\mathrm{PGE}_{2}, \mathrm{PGI}_{2}, \mathrm{~A} \beta$, or $\mathrm{A} \beta$ antibody or vehicle (PBS) solutions were injected (i.c.v) into WT or APP/ PS1 transgenic mice as previously described [60, 61]. In selected experiments, the WT mice were injected (i.c.v) with the CSF of APP/PS1 mice. Briefly, stereotaxic injections were placed at the following coordinates from the bregma: mediolateral: $-1.0 \mathrm{~mm}$; anteroposterior: -0.22 $\mathrm{mm}$; and dorsoventral: $-2.8 \mathrm{~mm}$. Following injections, each mouse recovered spontaneously on a heated pad. The reliability of injection sites was validated by injecting trypan blue dye (Invitrogen) into separate cohorts of mice and observing staining in the cerebral ventricles. Twentyfour hours after injection, mice were harvested under anesthesia and perfusion as previously described $[60,61]$.

\section{Organotypic slice culture of brain tissue}

Brain tissues were freshly collected from WT C57BL/6 mice at 6 months of age. Serial sections (400$\mu \mathrm{m}$ thick) were cut using a chopper without fixation. The tissue sections were immediately cultured in DMEM/ high glucose medium with $10 \%$ fetal bovine serum (FBS). In a separate set of experiments, the tissues were grown in serum-free medium for an additional $24 \mathrm{~h}$ before incubation with $\mathrm{A} \beta$ oligomers or fibrils, as previously described $[60,61]$. The tissue sections were fixed and immunostained with TNF- $\alpha$ antibody by an immunohistochemical staining kit.

\section{Luciferase assays and live animal imaging}

The D1A cells that were transfected with an TNF- $\alpha$ promoter were pre-seeded in one side of a ventricle. $\mathrm{PGI}_{2}$, $\mathrm{PGE}_{2}$ or vehicle (PBS) solutions were then injected (i.c.v) into the other side of ventricle. At different time intervals, mice were anesthetized and injected (i.c.v) with luciferin into the cerebral ventricle, which was preseeded with D1A cells. The scan was performed exactly after $5 \mathrm{~min}$ of luciferin introduction as previously described [60,61]. All images were taken and analyzed using Bruker in vivo imaging systems (MS FX PRO, Carestream, U.S.A).

\section{Luciferase promoter constructs}

A 2, 000-base pair (bp) TNF- $\alpha$ promoter construct, corresponding to the sequence from -1774 to +226 relative to the transcription start site of the 5'-flanking region of human TNF- $\alpha$ gene, was generated from human genomic DNA, using specifically designed forward 5'-TATCGAT AGGTACCGAGCTCCACTTCAGCCCCAGCAGTGT-3' and reverse 5 , GAT CGCAGATCTCGAGTTTTGGGGGAGTGCCTCTTC-3' primers incorporating $S a c 1$ and Xhol restriction sites (underlined) at the 5' ends and 3'ends, respectively. The amplicon was then inserted upstream of the luciferase reporter gene in the pGL3-basic vector (Promega). All construct sequences were confirmed using DNA 
sequencing.

\section{Promoter assay}

Firefly and Renilla luciferase activities were measured by use of the Dual-Luciferase Report Assay kit (Promega). Firefly luciferase activities were normalized to the Renilla luciferase controls. Data are expressed as ratios of shear to static normalized firefly luciferase activity unless otherwise stated.

\section{ChIP assay}

This assay was performed using the EZ ChIP kit following the manufacturer's instructions (Upstate Biotechnology) as described previously [62-65]. Forward (F) and reverse (R) primers for TNF- $\alpha$ promoter amplification by $\mathrm{qPCR}$ are as follows: F-atgcacccagctttcagaag and R- tctcggtttcttctccatcg.

\section{Quantitative real-time PCR (qRT-PCR)}

qRT-PCR assays were performed with the MiniOpticon Real-Time PCR detection system (Bio$\mathrm{Rad}$ ) using total RNA and the GoTaq one-step Real-Time PCR kit with SYBR green (Promega) and the appropriate primers as previously described [66]. The GenBank accession number and forward and reverse primers for mouse GAPDH and BACE- 1 are provided in our previous publications [59, 67, 68]: mouse TNF- $\alpha$ (NM_013693) F- tagctcccagaaaagcaagc, R- gggaacttctcatccetttg; PS1 (NM_008943) F- gcttgtaggcgcctttagtg, R- catctgggcattctggaagt; PS2 (NM_011183) Faagaacgggcagctcatcta, $\mathrm{R}$ - tccagacagccaggaagagt. The gene expression values were normalized to those of GAPDH.

\section{Western blot analysis}

Tissues or cells were lysed in radio-immune precipitation assay buffer $(25 \mathrm{mM}$ Tris- $\mathrm{HCl}[\mathrm{pH} 7.6]$, $150 \mathrm{mM} \mathrm{NaCl}, 1 \% \mathrm{NP}-40,1 \%$ sodium deoxycholate, and $0.1 \%$ SDS) that contained a protease inhibitor cocktail (Pierce Chemical Company). The protein content of the cell lysates was determined using the bicinchoninic acid (BCA) protein assay reagent (Pierce Chemical Company). The total protein lysates $(4 \mu \mathrm{g})$ were separated using SDS-PAGE, transferred to a membrane, and probed with a panel of specific antibodies. Each membrane was only probed with one antibody. $\beta$-actin was used as a loading control. All western hybridizations were performed at least in triplicate using a different cell preparation each time.

\section{Transfection}

The coding sequence of p38 was generated from mouse total mRNA, using specifically designed forward 5'- TTAAACT TAAGCTTGGTACCATGTCGCAGGAGAGGCCCAC-3' and reverse 5'-GATATCTGCA GAATTCTCAGGACTCCATTTCTTCTTGGTCAAG-3' primers, which was incorporated to pCDNA $3.1(+)$ vectors by Kpn 1 and EcoR 1 restriction sites (underlined) at the 5' ends and 3' ends, respectively. Similarly, the coding sequence of c-Jun was inserted to pCDNA 3.1 $(+)$ vectors by Kpn 1 and EcoR 1 restriction sites using specifically designed forward 5'-TTAAACTTAAGC TTGGTACCATGACTGCAAAGATGGAAACGACC-3' and reverse 5'-GATATC TGCAGAATTCTCAAAACGTTTGCAACTGCTGC-3' primers. Cells were transfected with $1.6 \mu \mathrm{g} / 6 \mathrm{~cm}$ dish of p38 or c-Jun cDNA plasmids. In control experiments, the cells were transfected with $100 \mathrm{nM}$ scrambled siRNA. The transfected cells were allowed to recover for at least $12 \mathrm{~h}$ in growth medium and then incubated overnight in serumfree medium before extraction. In live animal scanning experiments, the D1A cells were transfected with 1.6 $\mu \mathrm{g} / 6 \mathrm{~cm}$ dish TNF- $\alpha$ promoter plasmid for $48 \mathrm{~h}$ before screening the positive clones by puromycin. The positive clones were then injected or preseeded in the ventricles of mice.

\section{$A \beta_{1-42}$ preparation}

The methods for preparing $\mathrm{A} \beta$ oligomers or fibrils had been described previously [69]. In brief, freezedrying $\mathrm{A} \beta_{1-42}$ protein (Stock Number: A9810, Sigma, St. Louis, MO, USA) was initially monomerized by dissolving it to a final concentration of $1 \mu \mathrm{g} / \mu \mathrm{l}$ in $100 \%$ hexafluoroisopropanal (HFIP) and the solution was aliquoted in sterile eppendorf tubes. HFIP was then evaporated under vacuum and the peptide was stored at -20 ${ }^{\circ} \mathrm{C}$ before reconstituent. For preparing $\mathrm{A} \beta_{1-42}$ oligomers, the peptide was initially resuspended in dimethylsulfoxide (DMSO) to $20 \mu \mathrm{g} / \mu \mathrm{l}$ with water bath ultrasonication for $10 \mathrm{~min}$ and the solution was then diluted to a final concentration of $0.2 \mathrm{mg} / \mathrm{ml}$ in phenol red-free F-12 media, and incubated at $4^{\circ} \mathrm{C}$ for $24 \mathrm{~h}$. To prepare $A \beta_{1-42}$ fibrils, $A \beta_{1 \text {. }}$ ${ }_{42}$ was resuspended in sterile Milli $Q$ water and incubated at $37^{\circ} \mathrm{C}$ for 1 week before use.

\section{Immunohistochemistry}

Brain tissues were collected from WT or APP/PS1 transgenic mice. In selected experiments, brain tissues were collected after injection (i.c.v) of PGI $_{2}(2 \mu \mathrm{g} / 5 \mu \mathrm{l})$ or $\mathrm{PGE}_{2}(2 \mu \mathrm{g} / 5 \mu \mathrm{l})$. Serial sections $(5-\mu \mathrm{m}$ thick) were cut 
using a paraffin microtome (Leica, RM2235, Germany). Sections were first rehydrated in a graded series of ethanol and submerged in $3 \%$ hydrogen peroxide to eliminate endogenous peroxidase activity. The activity of TNF- $\alpha$ or $A \beta$ was determined by immunostaining TNF- $\alpha$ or $A \beta$ antibody using an immunohistochemical staining kit, following the manufacturer's instructions (Invitrogen, Carlsbad, CA, USA).

\section{Immunofluorescence}

Brain tissues were collected from WT or APP/PS1 transgenic mice. In selected experiments, brain tissues were collected after injection (i.c.v) of $\mathrm{PGI}_{2}(2 \mu \mathrm{g} / 5 \mu \mathrm{l})$ or $\mathrm{PGE}_{2}(2 \mu \mathrm{g} / 5 \mu \mathrm{l})$. Serial sections (10- $\mu \mathrm{m}$ thick) were cut using a cryostat (Leica, CM1850, Germany). Slides were stained with GFAPor Iba1 antibody with Alexa Fluor 555 secondary antibodies (Cell Signaling Technology, Inc., Danvers, MA, USA) before observing under confocal microscopy (Leica, TCS-SP8, Leica).

\section{Measurement of the TNF- $\alpha$ or $A \beta_{1-42}$ concentration in the culture medium or the brain of mice}

The TNF- $\alpha$ or $A \beta_{1-42}$ levels in the media of both control and pharmacologically treated cells or the brain of mice were determined using TNF- $\alpha$ or $A \beta_{1-42}$ enzyme immunoassay kits following the manufacturer's instructions. The total protein used for ELISA was used as a loading control, and the results are expressed as pg of TNF- $\alpha$ or pmol $A \beta_{1-42}$ per mg of total protein.

\section{Human brain samples}

Human brain samples were obtained from New York Brain Bank, serial numbers TT4263 (early stage of AD, the patient is 73-years-old man who was diagnosed as a mild AD patient), T4308 (middle stage of $\mathrm{AD}$, the patient is 86-years-old man who was diagnosed as moderate $\mathrm{AD}$ patient), T4339 and T4304 (late stage of AD, the patients are 88-years-old woman and 84 years-old woman who were diagnosed as severe and end stage of $\mathrm{AD}$ patients).

\section{Animal committee}

All animals were handled according to the care and use of medical laboratory animals (Ministry of Health, Peoples Republic of China, 1998) and all experimental protocols were approved by the Laboratory Ethics Committees of College of Life and Health Sciences of Northeastern University.

\section{Statistical analysis}

All data are represented as the mean \pm S.E. of at least three independent experiments. The statistical significance of the differences between the means was determined either using Student's $t$-test [59].

\section{ACKNOWLEDGMENTS}

This work was supported in part or in whole by the National Natural Science Foundation of China (CN) (31571064, 81500934, 31300777 and 31371091), the Fundamental Research Funds of China (N152004004, N142004002, N120520001, N120320001, N130120002, N141008001/7 and L1520001), the National Natural Science Foundation of Liaoning, China (CN) (2015020662) and the Liaoning Provincial Talent Support Program (LJQ2013029).

\section{CONFLICTS OF INTEREST}

The authors declare no competing financial interests.

\section{REFERENCES}

1. Montine TJ, Sidell KR, Crews BC, Markesbery WR, Marnett LJ, Roberts LJ 2nd, Morrow JD. Elevated CSF prostaglandin E2 levels in patients with probable AD. Neurology. 1999; 53:1495-98. https://doi.org/10.1212/ WNL.53.7.1495

2. Aisen PS, Schafer KA, Grundman M, Pfeiffer E, Sano M, Davis KL, Farlow MR, Jin S, Thomas RG, Thal LJ, and Alzheimer's Disease Cooperative Study. Effects of rofecoxib or naproxen vs placebo on Alzheimer disease progression: a randomized controlled trial. JAMA. 2003; 289:2819-26. https://doi.org/10.1001/jama.289.21.2819

3. Akarasereenont $\mathrm{P}$, Techatrisak $\mathrm{K}$, Chotewuttakorn S, Thaworn A. The induction of cyclooxygenase-2 in IL1beta-treated endothelial cells is inhibited by prostaglandin E2 through cAMP. Mediators Inflamm. 1999; 8:287-94. https://doi.org/10.1080/09629359990298

4. Ford-Hutchinson AW, Walker JR, Davidson EM, Smith MJ. PGI2: a potential mediator of inflammation. Prostaglandins. 1978; 16:253-58. https://doi.org/10.1016/00906980(78)90027-8

5. Heppner FL, Ransohoff RM, Becher B. Immune attack: the role of inflammation in Alzheimer disease. Nat Rev Neurosci. 2015; 16:358-72. https://doi.org/10.1038/ nrn3880

6. van Dijk G, van Heijningen S, Reijne AC, Nyakas C, van der Zee EA, Eisel UL. Integrative neurobiology of metabolic diseases, neuroinflammation, and neurodegeneration. Front Neurosci. 2015; 9:173. https:// doi.org/10.3389/fnins.2015.00173 
7. Trepanier $\mathrm{CH}$, Milgram NW. Neuroinflammation in Alzheimer's disease: are NSAIDs and selective COX-2 inhibitors the next line of therapy? J Alzheimers Dis. 2010; 21:1089-99. https://doi.org/10.3233/JAD-2010-090667

8. Cai Z, Hussain MD, Yan LJ. Microglia, neuroinflammation, and beta-amyloid protein in Alzheimer's disease. Int $\mathrm{J}$ Neurosci. 2014; 124:307-21. https://doi.org/10.3109/0020 7454.2013 .833510

9. Cimino PJ, Keene CD, Breyer RM, Montine KS, Montine TJ. Therapeutic targets in prostaglandin E2 signaling for neurologic disease. Curr Med Chem. 2008; 15:1863-69. https://doi.org/10.2174/092986708785132915

10. Hoshino T, Namba T, Takehara M, Nakaya T, Sugimoto Y, Araki W, Narumiya S, Suzuki T, Mizushima T. Prostaglandin E2 stimulates the production of amyloid-beta peptides through internalization of the EP4 receptor. J Biol Chem. 2009; 284:18493-502. https://doi.org/10.1074/jbc. M109.003269

11. Arvanitakis Z, Grodstein F, Bienias JL, Schneider JA, Wilson RS, Kelly JF, Evans DA, Bennett DA. Relation of NSAIDs to incident $\mathrm{AD}$, change in cognitive function, and AD pathology. Neurology. 2008; 70:2219-25. https://doi. org/10.1212/01.wnl.0000313813.48505.86

12. Szekely CA, Green RC, Breitner JC, Østbye T, Beiser AS, Corrada MM, Dodge HH, Ganguli M, Kawas $\mathrm{CH}$, Kuller LH, Psaty BM, Resnick SM, Wolf PA, et al. No advantage of A beta 42-lowering NSAIDs for prevention of Alzheimer dementia in six pooled cohort studies. Neurology. 2008; 70:2291-98. https://doi.org/10.1212/01. wnl.0000313933.17796.f6

13. Giri S, Rattan R, Singh AK, Singh I. The 15-deoxydelta12,14-prostaglandin J2 inhibits the inflammatory response in primary rat astrocytes via down-regulating multiple steps in phosphatidylinositol 3-kinase-AktNF-kappaB-p300 pathway independent of peroxisome proliferator-activated receptor gamma. J Immunol. 2004; 173:5196-208. https://doi.org/10.4049/ jimmunol.173.8.5196

14. Lee EO, Shin YJ, Chong YH. Mechanisms involved in prostaglandin E2-mediated neuroprotection against TNFalpha: possible involvement of multiple signal transduction and beta-catenin/T-cell factor. J Neuroimmunol. 2004; 155:21-31. https://doi.org/10.1016/j.jneuroim.2004.05.012

15. Pulichino AM, Rowland $\mathrm{S}, \mathrm{Wu} \mathrm{T}$, Clark $\mathrm{P}, \mathrm{Xu} \mathrm{D}$, Mathieu MC, Riendeau D, Audoly LP. Prostacyclin antagonism reduces pain and inflammation in rodent models of hyperalgesia and chronic arthritis. J Pharmacol Exp Ther. 2006; 319:1043-50. https://doi.org/10.1124/ jpet.106.110387

16. Kuo CH, Lin CH, Yang SN, Huang MY, Chen HL, Kuo PL, Hsu YL, Huang SK, Jong YJ, Wei WJ, Chen YP, Hung CH. Effect of prostaglandin $\mathrm{I} 2$ analogs on cytokine expression in human myeloid dendritic cells via epigenetic regulation. Mol Med. 2012; 18:433-44. https://doi.org/10.2119/ molmed.2011.00193
17. Kuo LH, Hu MK, Hsu WM, Tung YT, Wang BJ, Tsai WW, Yen CT, Liao YF. Tumor necrosis factor-alpha-elicited stimulation of gamma-secretase is mediated by c-Jun $\mathrm{N}$-terminal kinase-dependent phosphorylation of presenilin and nicastrin. Mol Biol Cell. 2008; 19:4201-12. https://doi. org/10.1091/mbc.E07-09-0987

18. Liao YF, Wang BJ, Cheng HT, Kuo LH, Wolfe MS. Tumor necrosis factor-alpha, interleukin-1beta, and interferongamma stimulate gamma-secretase-mediated cleavage of amyloid precursor protein through a JNK-dependent MAPK pathway. J Biol Chem. 2004; 279:49523-32. https://doi. org/10.1074/jbc.M402034200

19. Satoh J, Kuroda Y. Constitutive and cytokine-regulated expression of presenilin-1 and presenilin-2 genes in human neural cell lines. Neuropathol Appl Neurobiol. 1999; 25:492-503. https://doi.org/10.1046/j.13652990.1999.00209.x

20. Yamamoto M, Kiyota T, Horiba M, Buescher JL, Walsh SM, Gendelman HE, Ikezu T. Interferon-gamma and tumor necrosis factor-alpha regulate amyloid-beta plaque deposition and beta-secretase expression in Swedish mutant APP transgenic mice. Am J Pathol. 2007; 170:680-92. https://doi.org/10.2353/ajpath.2007.060378

21. Shi JQ, Shen W, Chen J, Wang BR, Zhong LL, Zhu YW, Zhu HQ, Zhang QQ, Zhang YD, Xu J. Anti-TNF- $\alpha$ reduces amyloid plaques and tau phosphorylation and induces CD11c-positive dendritic-like cell in the APP/PS1 transgenic mouse brains. Brain Res. 2011; 1368:239-47. https://doi.org/10.1016/j.brainres.2010.10.053

22. Xiang Z, Ho L, Yemul S, Zhao Z, Qing W, Pompl P, Kelley K, Dang A, Qing W, Teplow D, Pasinetti GM. Cyclooxygenase-2 promotes amyloid plaque deposition in a mouse model of Alzheimer's disease neuropathology. Gene Expr. 2002; 10:271-78. https://doi. org/10.3727/000000002783992352

23. Jeong YH, Hyun JW, Kim Van Le T, Kim DH, Kim HS. Kalopanaxsaponin A Exerts Anti-Inflammatory Effects in Lipopolysaccharide-Stimulated Microglia via Inhibition of JNK and NF-кB/AP-1 Pathways. Biomol Ther (Seoul). 2013; 21:332-37. https://doi.org/10.4062/ biomolther.2013.069

24. Vicil S, Erdoğan S. Beraprost sodium, a prostacyclin (PGI) analogue, ameliorates lipopolysaccharide-induced cellular injury in lung alveolar epithelial cells. Turk J Med Sci. 2015; 45:284-90. https://doi.org/10.3906/sag-1401-108

25. Yeh $\mathrm{CH}$, Kuo $\mathrm{CH}$, Yang $\mathrm{SN}$, Huang $\mathrm{MY}$, Wu $\mathrm{HC}$, Wang HP, Kuo TH, Hung CH. Prostaglandin I2 analogs suppress tumor necrosis factor $\alpha$ production and the maturation of human monocyte-derived dendritic cells. J Investig Med. 2011; 59:1109-15. https://doi.org/10.2310/ JIM.0b013e3182281f62

26. Wang WL, Kuo CH, Chu YT, Huang CH, Lam KP, Huang SK, Jong YJ, Kuo YT, Hung CH. Prostaglandin I(2) analogues suppress TNF- $\alpha$ expression in human monocytes via mitogen-activated protein kinase pathway. Inflamm 
Res. 2011; 60:655-63. https://doi.org/10.1007/s00011-0110317-6

27. Di Francesco L, Totani L, Dovizio M, Piccoli A, Di Francesco A, Salvatore T, Pandolfi A, Evangelista V, Dercho RA, Seta F, Patrignani P. Induction of prostacyclin by steady laminar shear stress suppresses tumor necrosis factor-alpha biosynthesis via heme oxygenase- 1 in human endothelial cells. Circ Res. 2009; 104:506-13. https://doi. org/10.1161/CIRCRESAHA.108.191114

28. Fujiwara K, Nagasaka A, Nagata M, Yamamoto K, Imamura S, Oda N, Sawai Y, Hayakawa N, Suzuki A, Itoh M. A stable prostacyclin analogue reduces high serum TNF-alpha levels in diabetic patients. Exp Clin Endocrinol Diabetes. 2004; 112:390-94. https://doi.org/10.1055/s-2004-821024

29. Wang P, Guan PP, Yu X, Zhang LC, Su YN, Wang ZY. Prostaglandin $\mathrm{I}_{2}$ Attenuates Prostaglandin $\mathrm{E}_{2}$-Stimulated Expression of Interferon $\gamma$ in a $\beta$-Amyloid Protein- and NFкB-Dependent Mechanism. Sci Rep. 2016; 6:20879. https:// doi.org/10.1038/srep20879

30. Hoshino T, Nakaya T, Homan T, Tanaka K, Sugimoto Y, Araki W, Narita M, Narumiya S, Suzuki T, Mizushima T. Involvement of prostaglandin E2 in production of amyloidbeta peptides both in vitro and in vivo. J Biol Chem. 2007; 282:32676-88. https://doi.org/10.1074/jbc.M703087200

31. Echeverria V, Clerman A, Doré S. Stimulation of PGE receptors EP2 and EP4 protects cultured neurons against oxidative stress and cell death following beta-amyloid exposure. Eur J Neurosci. 2005; 22:2199-206. https://doi. org/10.1111/j.1460-9568.2005.04427.x

32. Akitake Y, Nakatani Y, Kamei D, Hosokawa M, Akatsu H, Uematsu S, Akira S, Kudo I, Hara S, Takahashi M. Microsomal prostaglandin E synthase-1 is induced in alzheimer's disease and its deletion mitigates alzheimer's disease-like pathology in a mouse model. J Neurosci Res. 2013; 91:909-19. https://doi.org/10.1002/jnr.23217

33. Liu H, Deng Y, Gao J, Liu Y, Li W, Shi J, Gong Q. Sodium Hydrosulfide Attenuates Beta-Amyloid-Induced Cognitive Deficits and Neuroinflammation via Modulation of MAPK/ NF- $\kappa$ B Pathway in Rats. Curr Alzheimer Res. 2015; 12:673-83. https://doi.org/10.2174/156720501266615071 3102326

34. Lv C, Wang L, Liu X, Cong X, Yan SS, Wang Y, Zhang $W$. Geniposide attenuates oligomeric $A \beta(1-42)$-induced inflammatory response by targeting RAGE-dependent signaling in BV2 cells. Curr Alzheimer Res. 2014; 11:430 40. https://doi.org/10.2174/1567205011666140514111204

35. Detrait ER, Danis B, Lamberty Y, Foerch P. Peripheral administration of an anti-TNF- $\alpha$ receptor fusion protein counteracts the amyloid induced elevation of hippocampal TNF- $\alpha$ levels and memory deficits in mice. Neurochem Int. 2014; 72:10-13. https://doi.org/10.1016/j. neuint.2014.04.001

36. Díaz A, Rojas K, Espinosa B, Chávez R, Zenteno E, Limón D, Guevara J. Aminoguanidine treatment ameliorates inflammatory responses and memory impairment induced by amyloid-beta 25-35 injection in rats. Neuropeptides. 2014; 48:153-59. https://doi.org/10.1016/j. npep.2014.03.002

37. Kim M, Kim SO, Lee M, Lee JH, Jung WS, Moon SK, Kim YS, Cho KH, Ko CN, Lee EH. Tetramethylpyrazine, a natural alkaloid, attenuates pro-inflammatory mediators induced by amyloid $\beta$ and interferon- $\gamma$ in rat brain microglia. Eur J Pharmacol. 2014; 740:504-11. https://doi. org/10.1016/j.ejphar.2014.06.037

38. Jana M, Palencia CA, Pahan K. Fibrillar amyloid-beta peptides activate microglia via TLR2: implications for Alzheimer's disease. J Immunol. 2008; 181:7254-62. https://doi.org/10.4049/jimmunol.181.10.7254

39. Veerhuis R, Van Breemen MJ, Hoozemans JM, Morbin M, Ouladhadj J, Tagliavini F, Eikelenboom P. Amyloid beta plaque-associated proteins $\mathrm{C} 1 \mathrm{q}$ and SAP enhance the Abeta1-42 peptide-induced cytokine secretion by adult human microglia in vitro. Acta Neuropathol. 2003; 105:135-44. https://doi.org/10.1007/s00401-002-0624-7

40. He Y, Zheng MM, Ma Y, Han XJ, Ma XQ, Qu CQ, Du YF. Soluble oligomers and fibrillar species of amyloid $\beta$-peptide differentially affect cognitive functions and hippocampal inflammatory response. Biochem Biophys Res Commun. 2012; 429:125-30. https://doi.org/10.1016/j. bbrc.2012.10.129

41. Lindberg C, Selenica ML, Westlind-Danielsson A, Schultzberg M. Beta-amyloid protein structure determines the nature of cytokine release from rat microglia. J Mol Neurosci. 2005; 27:1-12. https://doi.org/10.1385/ JMN:27:1:001

42. White JA, Manelli AM, Holmberg KH, Van Eldik LJ, Ladu MJ. Differential effects of oligomeric and fibrillar amyloid-beta 1-42 on astrocyte-mediated inflammation. Neurobiol Dis. 2005; 18:459-65. https://doi.org/10.1016/j. nbd.2004.12.013

43. Welser-Alves JV, Milner R. Microglia are the major source of TNF- $\alpha$ and TGF- $\beta 1$ in postnatal glial cultures; regulation by cytokines, lipopolysaccharide, and vitronectin. Neurochem Int. 2013; 63:47-53. https://doi.org/10.1016/j. neuint.2013.04.007

44. Sawada M, Kondo N, Suzumura A, Marunouchi T. Production of tumor necrosis factor-alpha by microglia and astrocytes in culture. Brain Res. 1989; 491:394-97. https:// doi.org/10.1016/0006-8993(89)90078-4

45. Choi SS, Lee HJ, Lim I, Satoh J, Kim SU. Human astrocytes: secretome profiles of cytokines and chemokines. PLoS One. 2014; 9:e92325. https://doi.org/10.1371/journal. pone.0092325

46. Chung IY, Benveniste EN. Tumor necrosis factor-alpha production by astrocytes. Induction by lipopolysaccharide, IFN-gamma, and IL-1 beta. J Immunol. 1990; 144:29993007.

47. Lau LT, $\mathrm{Yu}$ AC. Astrocytes produce and release interleukin-1, interleukin-6, tumor necrosis factor alpha 
and interferon-gamma following traumatic and metabolic injury. J Neurotrauma. 2001; 18:351-59. https://doi. org/10.1089/08977150151071035

48. Blasko I, Marx F, Steiner E, Hartmann T, GrubeckLoebenstein B. TNFalpha plus IFNgamma induce the production of Alzheimer beta-amyloid peptides and decrease the secretion of APPs. FASEB J. 1999; 13:63-68.

49. Russo I, Caracciolo L, Tweedie D, Choi SH, Greig NH, Barlati S, Bosetti F. 3,6'-Dithiothalidomide, a new TNF- $\alpha$ synthesis inhibitor, attenuates the effect of A $\beta 1$ 42 intracerebroventricular injection on hippocampal neurogenesis and memory deficit. $J$ Neurochem. 2012; 122:1181-92. https://doi.org/10.1111/j.14714159.2012.07846.x

50. Badshah H, Ali T, Rehman S, Amin F, Ullah F, Kim TH, Kim MO. Protective Effect of Lupeol Against Lipopolysaccharide-Induced Neuroinflammation via the p38/c-Jun N-Terminal Kinase Pathway in the Adult Mouse Brain. J Neuroimmune Pharmacol. 2016; 11:48-60. https:// doi.org/10.1007/s11481-015-9623-Z

51. Park SY, Jin ML, Kim YH, Kim Y, Lee SJ. Antiinflammatory effects of aromatic-turmerone through blocking of NF- $\mathrm{BB}, \mathrm{JNK}$, and p38 MAPK signaling pathways in amyloid $\beta$-stimulated microglia. Int Immunopharmacol. 2012; 14:13-20. https://doi. org/10.1016/j.intimp.2012.06.003

52. Wu WY, Wu YY, Huang H, He C, Li WZ, Wang HL, Chen HQ, Yin YY. Biochanin A attenuates LPS-induced proinflammatory responses and inhibits the activation of the MAPK pathway in BV2 microglial cells. Int J Mol Med. 2015; 35:391-98. https://doi.org/10.3892/ijmm.2014.2020

53. Yang C, Yu L, Kong L, Ma R, Zhang J, Zhu Q, Zhu J, Hao D. Pyrroloquinoline quinone (PQQ) inhibits lipopolysaccharide induced inflammation in part via downregulated NF- $\mathrm{BB}$ and $\mathrm{p} 38 / \mathrm{JNK}$ activation in microglial and attenuates microglia activation in lipopolysaccharide treatment mice. PLoS One. 2014; 9:e109502. https://doi. org/10.1371/journal.pone.0109502

54. Zeng KW, Wang S, Dong X, Jiang Y, Tu PF. Sesquiterpene dimer (DSF-52) from Artemisia argyi inhibits microgliamediated neuroinflammation via suppression of NF- $\kappa$ B, JNK/p38 MAPKs and Jak2/Stat3 signaling pathways. Phytomedicine. 2014; 21:298-306. https://doi. org/10.1016/j.phymed.2013.08.016

55. Frey D, Jung S, Brackmann F, Richter-Kraus M, Trollmann R. Hypoxia Potentiates LPS-Mediated Cytotoxicity of BV2 Microglial Cells In Vitro by Synergistic Effects on Glial Cytokine and Nitric Oxide System. Neuropediatrics. 2015; 46:321-28. https://doi.org/10.1055/s-0035-1562924

56. Wang WY, Tan MS, Yu JT, Tan L. Role of proinflammatory cytokines released from microglia in Alzheimer's disease. Ann Transl Med. 2015; 3:136. https:// doi.org/10.3978/j.issn.2305-5839.2015.03.49atm-03-10-136

57. Clausen BH, Lambertsen KL, Babcock AA, Holm TH, Dagnaes-Hansen F, Finsen B. Interleukin-1beta and tumor necrosis factor-alpha are expressed by different subsets of microglia and macrophages after ischemic stroke in mice. J Neuroinflammation. 2008; 5:46. https://doi. org/10.1186/1742-2094-5-46

58. Bhaskar K, Maphis N, Xu G, Varvel NH, Kokiko-Cochran ON, Weick JP, Staugaitis SM, Cardona A, Ransohoff RM, Herrup K, Lamb BT. Microglial derived tumor necrosis factor- $\alpha$ drives Alzheimer's disease-related neuronal cell cycle events. Neurobiol Dis. 2014; 62:273-85. https://doi. org/10.1016/j.nbd.2013.10.007

59. Wang P, Guan PP, Wang T, Yu X, Guo JJ, Wang ZY. Aggravation of Alzheimer's disease due to the COX-2mediated reciprocal regulation of IL- $1 \beta$ and $A \beta$ between glial and neuron cells. Aging Cell. 2014; 13:605-15. https:// doi.org/10.1111/acel.12209

60. Wang P, Yu X, Guan PP, Guo JW, Wang Y, Zhang $\mathrm{Y}$, Zhao H, Wang ZY. Magnesium ion influx reduces neuroinflammation in $\mathrm{A} \beta$ precursor protein/Presenilin 1 transgenic mice by suppressing the expression of interleukin-1 $\beta$. Cell Mol Immunol. 2017; 14:451-64. https://doi.org/10.1038/cmi.2015.93

61. Yu X, Guan PP, Guo JW, Wang Y, Cao LL, Xu GB, Konstantopoulos K, Wang ZY, Wang P. By suppressing the expression of anterior pharynx-defective- $1 \alpha$ and $-1 \beta$ and inhibiting the aggregation of $\beta$-amyloid protein, magnesium ions inhibit the cognitive decline of amyloid precursor protein/presenilin 1 transgenic mice. FASEB J. 2015; 29:5044-58. https://doi.org/10.1096/fj.15-275578

62. Guan PP, Guo JW, Yu X, Wang Y, Wang T, Konstantopoulos K, Wang ZY, Wang P. The role of cyclooxygenase-2, interleukin- $1 \beta$ and fibroblast growth factor-2 in the activation of matrix metalloproteinase- 1 in sheared-chondrocytes and articular cartilage. Sci Rep. 2015; 5:10412. https://doi.org/10.1038/srep10412

63. Guan PP, Yu X, Guo JJ, Wang Y, Wang T, Li JY, Konstantopoulos K, Wang ZY, Wang P. By activating matrix metalloproteinase-7, shear stress promotes chondrosarcoma cell motility, invasion and lung colonization. Oncotarget. 2015; 6:9140-59. https://doi. org/10.18632/oncotarget.3274

64. Wang P, Zhu F, Konstantopoulos K. Interleukin-6 synthesis in human chondrocytes is regulated via the antagonistic actions of prostaglandin (PG)E2 and 15-deoxy- $\Delta(12,14)-$ PGJ2. PLoS One. 2011; 6:e27630. https://doi.org/10.1371/ journal.pone.0027630

65. Wang P, Zhu F, Tong Z, Konstantopoulos K. Response of chondrocytes to shear stress: antagonistic effects of the binding partners Toll-like receptor 4 and caveolin-1. FASEB J. 2011; 25:3401-15. https://doi.org/10.1096/fj.11184861

66. Wang P, Zhu F, Lee NH, Konstantopoulos K. Shearinduced interleukin- 6 synthesis in chondrocytes: roles of E prostanoid (EP) 2 and EP3 in cAMP/protein kinase Aand PI3-K/Akt-dependent NF-kappaB activation. J Biol Chem. 2010; 285:24793-804. https://doi.org/10.1074/jbc. 
M110.110320

67. Wang $\mathrm{P}$, Chen SH, Hung WC, Paul C, Zhu F, Guan PP, Huso DL, Kontrogianni-Konstantopoulos A, Konstantopoulos K. Fluid shear promotes chondrosarcoma cell invasion by activating matrix metalloproteinase 12 via IGF-2 and VEGF signaling pathways. Oncogene. 2015; 34:4558-69.

68. Wang $\mathrm{P}, \mathrm{Zhu} \mathrm{F}$, Konstantopoulos $\mathrm{K}$. The antagonistic actions of endogenous interleukin-1 $\beta$ and 15-deoxy$\Delta 12$,14-prostaglandin $\mathrm{J} 2$ regulate the temporal synthesis of matrix metalloproteinase-9 in sheared chondrocytes. J Biol Chem. 2012; 287:31877-93. https://doi.org/10.1074/jbc. M112.362731
69. Dahlgren KN, Manelli AM, Stine WB Jr, Baker LK, Krafft GA, LaDu MJ. Oligomeric and fibrillar species of amyloidbeta peptides differentially affect neuronal viability. J Biol Chem. 2002; 277:32046-53. https://doi.org/10.1074/jbc. M201750200 